\title{
Ideological and real socialism of my Soviet childhood, schooling, and teaching: Multi-consciousness ${ }^{1}$
}

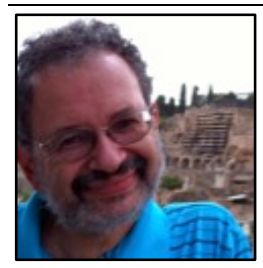

Eugene Matusov

University of Delaware, USA

\begin{abstract}
Through my autobiographical reflective ethnography of my Soviet childhood, schooling and teaching, I try to investigate the phenomenon of political multiple consciousness that I observed in the USSR and its development in children. In my analysis, I abstracted eight diverse types of consciousness, five of which are political in their nature.
\end{abstract}

Eugene Matusov is a Professor of Education at the University of Delaware. He studied developmental psychology with Soviet researchers working in the Vygotskian paradigm and worked as a schoolteacher before immigrating to the United States. He uses sociocultural and Bakhtinian dialogic approaches to education. His recent books are: Matusov, E. (2017). Nikolai N. Konstantinov's authorial math pedagogy for people with wings, Matusov, E. \& Brobst, J. (2013). Radical experiment in dialogic pedagogy in higher education and its Centauric failure: Chronotopic analysis, and Matusov, E. (2009). Journey into dialogic pedagogy.

$\cos (\operatorname{sic} 80$

\section{Introduction}

Famous Soviet comedian Mikhail Zhvanetsky commented in one of his 1970 s monologue that it was very difficult to learn what exactly a Soviet person thought on any issue. He suspected that the answer could be given only through a physiological examination of the person's body, "A person who says 'yes' undergoes a careful examination to check if behind this 'yes' is lurking hidden 'no'. The exact answer can be achieved only by a urine test, which is very difficult to obtain from the person" (Zhvanetsky, 2001, p. 175 , translation from Russian is mine). For the purpose of this investigation, I define a type of political consciousness heuristically as somewhat consistent subjectivity. The goal of this essay is to investigate this phenomenon of political multiple consciousness in the totalitarian country of the Soviet Union through my autobiographical memoir of my Soviet childhood, schooling and teaching.

In my autobiographical memoir focused on my Soviet childhood and schooling of the 1960s-1970s and, to a lesser degree, of my role as a Soviet physics teacher in Moscow in the 1980s, which is commonly considered as a "post-totalitarian" or "cold" Communist regime (cf. Vaclav Havel), I want to consider several important mutually related puzzles. The first puzzle is about the relationship of Soviet people with the Soviet

${ }^{1}$ I am thankful to Alexander and Olga Bromberg, Marek Tesar, Ana Marjanovic-Shane, Lei Chen, Iveta Silova, and Helen Aydarova for their encouragement, feedback, support, and discussions of previous drafts of the paper. 
official totalitarian ideology of Communism: did the people under totalitarianism really believe in the totalitarian ideology? Several past cultural critics and political science scholars commented on the phenomenon of double-consciousness among people oppressed by totalitarianism (e.g., Orwell, DuBois, Wertsch, Havel, and so on). But in my personal historical experience, the phenomenon was more complex that would allow me to talk about political multiple consciousness, rather than just double.

My second major inquiry is developmental: how did these diverse political consciousnesses emerge in Soviet children through their socialization and reply to the Soviet (post)totalitarianism?

My third major inquiry involves the relationship between "ideological" and "real" socialism, which were not mutually exclusive. I want to treat these two terms with ambiguity as it allows me to reveal the historical Soviet totalitarian socialism, with its egalitarian and collectivity promises, through the eyes of a child (i.e., mostly me but also my peers). The issue for me here is not only or even mainly of whether the ideological socialism delivered its promises, but also of whether these promises and aspirations were good in the first place. I want to present diverse stories, voices, and events with diverse foci on ideology, class, gender, nationality, history, Soviet imperialism, Soviet nationalism, Soviet communism, Soviet totalitarianism, and Soviet colonialism. At the same time, in this autobiographical memoir critical ethnography, I want to provide glimpses of how my friends, my peers, my parents, my teachers, my colleagues, and I made sense out our lives, our childhood, our education, and our being together that were full of joy, adventures, meaningful events, love, creative agency, drama, boredom, mistakes, mischiefs, crimes, and pains. My goal was not so much to typify my particular experiences and reflective observations but rather to make sense of my particular experiences and observations and to build plausible hypotheses, which may or may not be generalizable to a bigger population or to different totalitarian regimes or in their different phases. I tried to bring literature whenever I could to compare and contrast it with my own findings. My reflective patterns emerge from my "thick memory descriptions" (cf. Geertz, 1973), united, but not entirely limited, by my grounded inquiries. I tried to create a multi-dimensional and multi-discourse storybased picture of a particular Soviet childhood and schooling, coming from particular vistas and experiences of mine.

\section{Socialization of a child in the Soviet post-totalitarian socialism: Multiple political consciousness}

\section{Major multiple political consciousness in the USSR}

I was born and raised in Soviet post-totalitarian ${ }^{2}$ socialism that, in my observation, was characterized by the triple major political consciousness phenomenon among many (but not all) Soviet

\footnotetext{
${ }^{2}$ Czech dissident, playwright, and, after the 1989 Velvet Revolution, President of Czechoslovakia, Vaclav Havel coined the term "posttotalitarian" in this essay, "I do not wish to imply by the prefix 'post-' that the system is no longer totalitarian; on the contrary, I mean that it is totalitarian in a way fundamentally different from classical dictatorships..." (Havel \& Keane, 1985, p. 27). Havel biographer, John Keane, describes Havel's definition of a post-totalitarian world: "Within the system, every individual is trapped within a dense network of the state's governing instruments... themselves legitimated by a flexible but comprehensive ideology, a 'secularized religion'... it is therefore necessary to see, argued Havel, that power relations... are best described as a labyrinth of influence, repression, fear and self-censorship which swallows up everyone within it, at the very least by rendering them silent, stultified and marked by some undesirable prejudices of the powerful..." (Havel \& Keane, 1985, pp. 273-274). For me, post-totalitarianism, "cold" totalitarianism, is characterized by the administrative command management but already without mass terror, mass repressions, and organized mass hysteria and fanaticism - common for the acute "hot" totalitarianism of the Stalinist era, - while the official totalitarian ideology remaining omnipresent, total, and ubiquitous.

A scholar of Vaclav Havel, Marek Tesar argued in his response to this paper, "I also believe that Havel's work is not a good fit for your paper. We could have a long discussion around this but basically Havel's post-totalitarian thinking is very much linked with Czechoslovakia - and based upon particular turns of events. The way I see this concept based upon studying Havel's philosophical legacy, is as non-transferable but relatable, if that makes sense. But I am not sure that you can use this concept in relation to the Soviet Union." However, with this caveat, it is appropriate to induce Havel's term to the post-Stalinist USSR, if not conceptually then metaphorically. A further political analysis is probably needed.
} 
citizens. The three types of Soviet post-totalitarian consciousness were the following. The first type of major political consciousness involved expected performance of the official ideology of the day in official public settings with the participants enacting official roles. However, people did not necessarily believe in the ideology that they performed. They performed the official for different reasons - under pressure of the Soviet authorities, to show loyalty, to be safe, to have a career, and so on. The second type of major political consciousness involved a person's private beliefs, critical of the Soviet regime. This type of consciousness was often grounded in spicy political jokes, keen critical observations on the Soviet reality and sharp metaphorical judgments, shared with friends, relatives and confidants in informal intimate social settings, a "private-public sphere" (Voronkov \& Chickadze, 1997). The third major political consciousness involved deeply imprinted and accepted official ideology that was shared and enacted with genuine enthusiasm, creativity, and self-generated initiatives regardless of an audience or a situation. My school principal, in a Moscow school where I worked as a physics teacher from 1982 to 1985, is a good example of the Soviet triple consciousness.

One time she entered my classroom, looked around at the classroom walls covered with scientific posters, and reprimanded me for a lack of any political display. I tried to defend myself, that I taught physics and not an ideological academic subject like history, literature or geography, but the principal interrupted me and said, "In the Soviet Union, any teacher is $95 \%$ an ideological worker and only $5 \%$ a predmetnik [i.e., an academic subject teacher, in Russian]." I had plenty of evidence that she did not believe in this claim herself. She had a great interest in pedagogy, being a very creative and innovative teacher of geography herself. She was among a few of my colleagues in the school, with whom I could seriously and deeply discuss diverse educational and pedagogical issues. For example, she was very interested in learning children's indigenous views about geographical issues - i.e., exploring children's own intuitive geographical understandings. As a teacher with an arguably progressive educational philosophy, she was constantly thinking about how to bridge students' indigenous subjectivities and the state-imposed curriculum. Thus, in my judgment, she was a true "predmetnik." She also helped and valued me, a novice physics teacher, exactly for my deep knowledge of physics, my passionate commitment to science, and my desire to improve my pedagogy - the same 5\% that she was talking about in her official speech - as she told me and my school colleagues on many occasions. She valued pedagogical professionalism in teachers and was often dismayed at ideological requirements imposed on us. I remember that during a physics exit school exam ${ }^{3}$, a student cleverly decided to use official Communist ideology to mask his lack of physics knowledge. She cut him off by saying that this was a physics exam and not a "social studies" exam, where the official Communist ideology was dominating. However, on that particular occasion that I described above, she performed an expected official role of the ideological supervisor, assuming a role of a party functionary. I did not know what triggered this role in her at that moment just between the two of us but I suspect that it was some kind of an external event rather her own initiative. It seemed to me that it was her own creative enactment of an external pressure. Probably it was some kind of warning to me. At that time, every classroom in every Soviet school should have at least a portrait of Lenin, the cherished Communist leader of the past, but my physics classroom did not. When I assumed the ownership of the physics classroom, I took all the ideological posters and portraits and replaced them with science displays. In the early 1980s, it seemed unclear for the school officialdom - the administration, Party, and trade union leaders - how much these rituals were habitual or formal official requirements. This made them uneasy: following the official outdated line too zealously might cause them to be viewed as stupid in the eyes of their colleagues (and their own eyes), but a too lenient attitude toward a novice young teacher could be seen as a political myopia worth of a severe reprimand, in case the political requirement would be (suddenly) not considered outdated

\footnotetext{
${ }^{3}$ At the end of Soviet high school all students must take and pass exit exams in many academic subjects to get a high school diploma administrated by local schools (i.e., teachers and the school administrators). The exams were designed by the state ministry of education.
} 
by the Communist officialdom. When I taught physics, I was supposed to pepper some current ideological stuff, like decisions of the recent Party Congress regarding technology and science or Soviet science achievements or quotes from the General Secretary of the Communist Party ${ }^{4}$, in my physics lessons but I never did it. I skipped school local Communist party meetings on a regular basis - although I was not a party member or a member of the Communist Youth Organization (Komsomol). However, everybody, including non-party members, had to attend to local "open party meetings." My ideological truancy and neglect to the performance of loyalty to the official ideology raised an eyebrow of many of my school officials - local party and trade union bosses, - which probably led my principal to the enactment of her first, performative, consciousness of the ideological officialdom. Later I was called for an official meeting and was threatened with a severe punishment of reduction of my workload (and, thus, salary) but the threat was never realized probably due to shortages of teachers and my enthusiastic acceptance of the punishment because I had a second, much more profitable, job in the Soviet shadow economy of tutoring.

My principal's second, critical, consciousness of the private criticism of the Soviet reality popped up here and there in informal settings, in which I was present. I do not remember my principal sharing with me political jokes, although I did not have doubts that she did it with her friends. She used sharp critical language to describe the Soviet reality when she felt irritated by it. For example, when in November 1982 the General Secretary of the Communist Party Leonid llich Brezhnev died, the Soviet schools were ordered to have students of all grades in classrooms but not to conduct any academic lessons. Students were locked in their home classrooms to watch the TV playing mourning music and official speeches, praising Brezhnev's political, economic, and military achievements. Young students were also asked to draw patriotic and ideological pictures. It was a big toll of boredom on the students and teachers who had to control them. As a first-year novice teacher, I was not a homeroom teacher and did not have these obligations to babysit my homeroom students. Since I could not teach on these days, I decided to leave school early and go home. At the exit door, I was caught by my school principal. She realized that I was leaving the school, which was problematic from the point of view of the official ideology requiring all workers to stay at their workplaces and collectively mourn the deceased officially loved Communist Leader. Surprisingly to me, she asked me, "Can you walk around the school until this petrushka is over?" It was clear for me that she sanctioned my leaving the school. Of course, I promised her to do that but instead immediately went home. We understood each other well. She somewhat sanctioned my leaving without an overt permission. Her word choice to characterize the annoying event as a "petrushka" was very symptomatic of her first private critical consciousness. The Russian colloquial word "petrushka" is defined by a Russian dictionary as "1) Doll, the main comic character in the popular Russian puppetry [similar to the British puppet character Punch]. 2) Something absurd, strange, funny (colloquial: humorous)" (http://www.vedu.ru/expdic/22833/). The principal clearly used the second meaning to describe the comically absurd mourning ceremony of the Brezhnev funeral. In another example of her private critical consciousness, a day after she officially denounced my private tutoring ${ }^{5}$, she called me for a private chat and asked if I could tutor her nephew.

Yet, when I left the school in 1985, I found myself in a strange situation, reflecting my principal's third major political consciousness, truly believed in the Soviet ideology of the officialdom. I applied for physics teacher jobs at schools near my place of living, which was in the same school district where I was

\footnotetext{
${ }^{4}$ Interesting enough, Soviet school physics textbooks of the early 1980s when I was teaching did not have much ideological Communist stuff. For example, in the 9-grade physics textbook that I used in my teaching, I found only one reference to socialism, "The solutions of the listed above [ecological] problems is a life important task of the humanity. And these problems can be solved with the maximum success in a socialist society with its planned economy. However, the organization of ecological protection requires efforts on the scale of the entire globe" (Buhovtsi, Klimontovich, \& Myakishev, 1982, pp. 72-73). Other ideological material in this physics textbook involved its focus on the Russian and Soviet national achievements in the science (sometimes exaggerated) - see below my discussion of the Soviet Nationalist Socialism.

${ }^{5}$ Any earning money outside of a state job was illegal in the Soviet Union and viewed as a state crime.
} 
previously employed. I succeeded in being hired several times. However, before I could start my new job, mysteriously I was told that the position was closed. On the third of such occurrence, a colleague of mine, whom I knew from my professional activity in the district privately, contacted and told me that for some reasons, unknown to her, I was on the district's "black list" as "politically disloyal." A few days later, a teacher colleague from my old school told me that she overheard the school principal telling her confidant viceprincipal ("zavuch") that she added my name to the district's "black list" because I was ideologically corrupting children in the principal's view. As far as I know from talking with Soviet principals, it was my school principal's creative initiative, as assessing political loyalty of teachers was not required by the district at that time. She seemed to genuinely believe that, although I never discussed political issues with my students, my too free and frank non-ideological discussions with the students of other issues like rock music, modern art, pedagogy, and so on were authentically viewed by her as ideologically corruptive for schoolchildren. She was probably right about that because my free-spirited discussions indeed probably nurtured free non-totalitarian thinking and liberal attitudes in some of my students ${ }^{6}$. Her conviction that free liberal thinking was corrupting for school children was probably genuine and, thus, I presented a genuine threat to her political and moral beliefs that she tried to creatively address by putting my name into a school district black list of "politically unreliable." Fortunately for me, Moscow had several school districts that did not share their political black lists at that time, prior to computerization?

By my 20 s in the 1980s, I had probably developed a quadruple political consciousness. My fourth consciousness was active participation in both politically and non-politically diverse underground movements - I became a (political) spoilsport of the Soviet post-totalitarian regime ${ }^{8}$. With my friends, I published underground literary, art, and music journals, photo copied illegal samizdat, had quit Komsomol, did not participate in Soviet one party one candidate elections, attended underground political meetings, organized illegal private tutoring, read illegal anti-Soviet literature, created a conceptualism art group, and participated in a 2-person political demonstration against the Soviet invasion of Afghanistan (Kushnir, Gurev, \& Volkov, 1994; Tamruchi, 1995). As a part of this fourth consciousness, I tried to maximize the sphere of private critical consciousness, to minimize the first sphere of official performance, and to eliminate the third sphere of uncritical beliefs in the Soviet propaganda and ideology. However, I can recognize only now that the latter was only partially successful. In my youth, I still uncritically subscribed to the Soviet ideological ideas that a person should sacrifice his/her interests, if not his/her life, for the embetterment of the entire society, a person should not try to pursue his/her material interests too much and do not become a material consumer, no economic relationship should penetrate friendship, communism is desirable, and so on (and I may still subscribe to them now in ways that remain invisible to me). I think now that these were not a result of an overlap of my own private beliefs with the Soviet official ideology but rather my uncritical socialization to these ideas, which probably resulted from my lack of exposure to alternative ideas and critical discussions of them with other people. Alternative ideas were scarce in the Soviet Union with its repressive censorship and totalitarian propaganda. Samizdat and dissidents were in a scarce supply even for people like me, who were actively searching for these sources.

\footnotetext{
${ }_{7}^{6}$ About ten years ago, I was contacted by some of my past students and they confirmed that suspicion.

${ }^{7}$ I wonder whether or not that Moscow school district alerted KGB - the state secret police - about my political disloyalty or not.

8 "The player who trespasses against the rules or ignores them is a 'spoil-sport.' The spoil-sport is not the same as the false player, the cheat; for the latter pretends to be playing the game and, on the face of it, still acknowledges the magic circle. It is curious to note how much more lenient society is to the cheat than to the spoil-sport. This is because the spoil-sport shatters the play-world itself. By withdrawing from the game he reveals the relativity and fragility of the play-world in which he had temporarily shut himself with others. He robs play of its illusion - a pregnant word which means literally "in-play" (from inlusio, illudere or inludere). Therefore he must be cast out, for he threatens the existence of the play-community. ... The spoil-sport breaks the magic world, therefore he is a coward and must be ejected. In the world of high seriousness, too, the cheat and the hypocrite have always had an easier time of it than the spoil-sports, here called apostates, heretics, innovators, prophets, conscientious objectors, etc." (Huizinga, 2009, pp. 11-12, I am thankful to Ana Marjanovic-Shane for finding this quote).
} 
If a majority of "common" Soviet Russian people who surrounded me in Moscow had all three spheres of their triple consciousness equally developed, "common" Soviet people, national minorities, living in some Soviet republics like Estonia, Latvia, Lithuania had a very big private critical sphere and a very small (if at all) sphere of genuine belief in the Soviet official ideology. Empirical research by American sociocultural psychologist James Wertsch supports my observation. Wertsch (2002) described Estonian double consciousness - the private-public critical and the official totalitarian - in how Estonian high school students could successfully pass Soviet history exams that claimed that Estonia voluntarily joined the USSR in the summer 1940 because of the demands of Estonian workers, while these same students retained their private beliefs in the Soviet military occupation of their then independent democratic country. Similarly, many people in Eastern European Soviet satellites, so-called "countries of people's democracy," perceived their socialism as the Soviet occupation, the triple consciousness of post-totalitarianism collapsed into the double consciousness of the private critical sphere and the sphere of official performance (Havel \& Keane, 1985). As to the historical time of the acute "hot" Soviet totalitarianism of the Stalinist USSR (1929-1953), based on stories by my parents and their friends, I suspect that the third sphere of genuine and passionate beliefs in the Soviet ideology was very thick while the first sphere was very thin.

The relationship among diverse types of the (post-)totalitarian multiple political consciousnesses were various. In my observation, for the most Soviet citizens, they tried to keep these three types separate depending on clearly separated domains, situations, participants, and settings - most people did not try to register or resolve their contradictions among the 3 types of consciousness, governed by particular contexts. For example, in one context of her biographical account, my grandma might tell me - her teenage grandson - that about 10 neighbors "disappeared" in one night from their Moscow communal apartment during the Stalinist purges of 1937-1938 (i.e., they all were arrested by NKVD ${ }^{9}$, then secret police), and never came back. While in another context of a political discussion, she would claim to me that she knew nothing about the Stalinist purges, probably worrying about my possible involvement with a dissent movement. When I reminded her about her own recollection of the purge, she told me that she was afraid of thinking about that then and even now. Some people experienced the Stalinist terror and totalitarianism, learned to deny their own memory and eradicated it from any contradictions entirely, as sometimes my father and people of his generation did, who grew up during the Stalinist acute "hot" totalitarianism. It was probably a defensive psychological mechanism against accidental slipping into revealing unpleasant unofficial truth (Roviello \& Temerson, 2007). As Hannah Arendt (1966) argued, totalitarianism makes people lose their ground, which may involve defensive losing their memory. I argue that this loss of ground leads to the phenomenon of multiple political consciousness. Yet, many people in the Baltic Soviet Republics often perceived the USSR as an occupation - viewing their life under Soviet occupation, while publically repeating the Soviet official propaganda, was their way to integrate their multiple (double) consciousness. Some Soviet dissidents took a heroic stand by integrating their consciousnesses into one consciousness - the fifth consciousness - of "living in truth and not by lie" through active political struggle with the regime ${ }^{10}$ (Havel \& Vladislav, 1989; Solzhenitsyn, 1974b; Yurchak, 2006). Yet, many other nonconformists, like me, preferred "internal immigration" (Wertsch, 2002) of non-participation in the regime, internal and private dialogue of critique (Bukovsky, 1979), and our moral support to active dissidents (the fourth consciousness).

\footnotetext{
${ }^{9}$ Later to become known as KGB.

${ }^{10}$ My own involvement in the dissident consciousness reached the peak in my late 20s by my participation in two-people demonstration against the Soviet invasion of Afghanistan in 1987 during Gorbachev's perestroika. My friend and I were arrested by KGB officers after just about $15 \mathrm{~min}$ of our demonstration in the center of Moscow, in an underground pass during a rush hour, and transferred to the city police for joint KGB-police multi-hour interrogation. At the end we got subpoena to come to a court for sentencing and were released from the KGB-police custody. My friend and I ignored the subpoena and did not come to the court. However, a group of people who demonstrated a few days after us in the same place for the same cause were very severely beaten by KGB officers many of them ended up in hospitals.
} 


\section{Emergence of multiple political consciousnesses in Soviet childhood}

In the post-totalitarian Soviet society, many children were not born or actively taught the ubiquitous triple consciousness, but rather this triple consciousness emerged gradually through the following consecutive processes that I observed on myself and other Soviet children. The first process was usually the total brainwash and uncritical socialization of very young children in the Soviet official ideology in nursery school, kindergarten, and grade school, through children and adult media, parents, official political events, and even peers. For example, when I was 7-year old, I wrote the following poem:

Look, see the Revolution has come,

That moment of Victory is on us!

And with the Red flag as usual

We are going to the Lenin Mausoleum! $!^{11}$

When I was 8, we moved to another, bigger apartment in Moscow, and I had my own room for the first time.

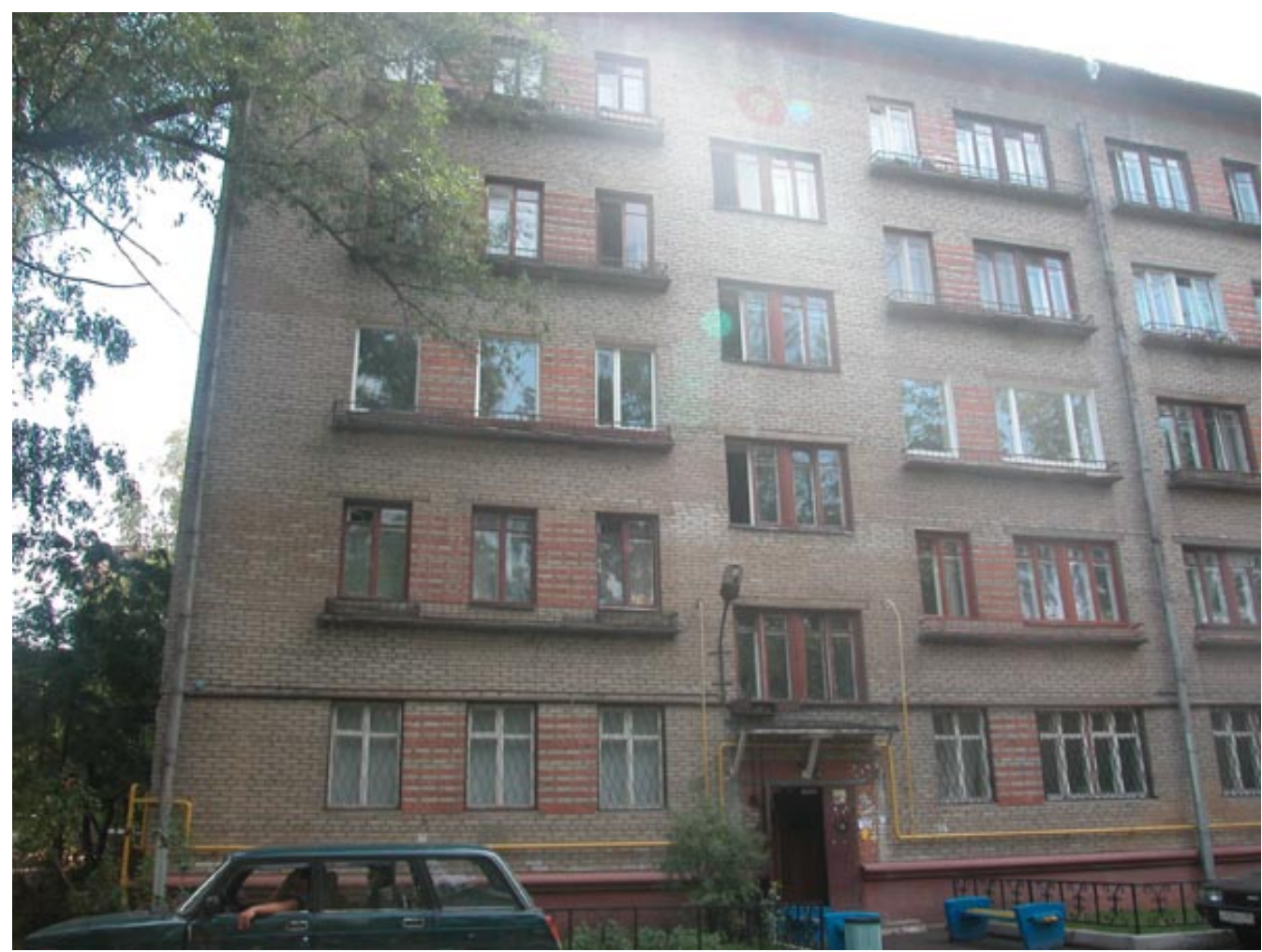

Picture 1. I lived in this building from 1968 until 1974/1977 on the fifth floor on the left (photo is mine, 2002)

One of my first responses to having a separate room of mine own was to create a Lenin museum by cutting pages with his picture from a children's book about young Lenin and gluing these pages on the newly fixed wallpaper of my room. Despite their apparent disappointment of my ruining freshly fixed wallpaper with glue, my parents did not scold or punish me but patiently and tactfully explained that although

Вот Революция пришла,

Пришёл тот миг Победы!

И с Красным фрлагом, как всегда,

Идём мы к Мавзолею. 
my worshiping of Grandpa Lenin was admirable, only the Communist Party could sanction Lenin museums. They took all the pages down carefully from the wallpaper and rearranged the furniture in my room to cover the damage left by the glue until they replaced the wallpaper. I also remember teaching my 6-year old cousin that without Lenin both of us would not born -- I was eight then. In the recent 2014 documentary "Stateless" by Michael Drob (http://www.stateless.us) about Russian Jewish immigrants from the Soviet Union to the United States in the late 1980s (exactly when I also immigrated from the USSR), a parent of a 5-year old daughter overheard her arguing with another little boy, while they were waiting for an entrance interview in the American consulate in Rome to receive a US refugee status. The boy claimed that God was the most important and powerful because God controlled everything. But the girl argued that it was Lenin (the mother tried fiercely to silence her daughter being afraid to fail the interview in the American consulate and to be unable to enter the USA as a refugee for political and religious persecutions). Similar stories about their Communist childhood have been reported in memoirs of people who were born in the post-totalitarian USSR (e.g., Shteyngart, 2014). Of course, I suspect that in some households, young children were protected from their contact with the official propaganda (like we did with our son by preventing him from attending any official Soviet child institution before we immigrated to the US in 1988) or even exposed their children to critique of the Soviet totalitarian regime. However, in my personal observations such cases were rare exceptions. In summary, many young Soviet children in the posttotalitarian era were actively socialized into the third and only sphere of the genuine beliefs in the Soviet official ideology.

However, this solo domination of the genuine beliefs in the Soviet ideology by young Soviet children could not be sustained in the post-totalitarian Soviet Union for several reasons. First, as my parents tried to teach me, personal initiatives, unauthorized and unsanctioned by the Communist state officialdom, could be very dangerous, regardless of how pure and true were the beliefs in these initiatives. One could passionately worship Lenin but one could not create Lenin's shrine on his or her own initiative, without an explicit permission of the Soviet Party officialdom. In totalitarianism, everything that was not explicitly and officially permitted, was forbidden. Creativity and initiative of people had to be well organized and directed from above in the post-totalitarian USSR. A consciousness of authorial agency based on creativity, personal initiative, and personal responsibility was viewed by the Soviet officialdom, at least, with suspicion and often was suppressed and severely punished. Actions of Soviet people had to be officially sanctioned and socially ordered by the Party-State authority. Unsanctioned or unordered actions were viewed anti-Soviet by default. For example, my late teenage friends, romantic Che Guevaran Communards (Sidorkin, 1995), were first "guided" and then warned by a local youth party boss for their unsanctioned protests against American capitalists' exploitation of workers around the American embassy in Moscow in the late 1970s and then, when they fiercely persisted, they were threatened by a KGB officer who visited them.

The second reason for which the official passionate beliefs could not be sustained was that often (if not always!) the Soviet ideology said one thing but meant another, often the opposite, thing. Young people had to learn double-speech (Orwell, 1992): to understand what was said for raising passions and loyalty and to understand what the real limitations of their actions must be. For example, the Soviet propaganda and the Soviet Constitution said that the Soviet Union had freedom of speech, freedom of assembly, and freedom of press but Soviet reality was drastically different: using censorship, repressions, and prisons to eliminate these freedoms (Bernholz, 1991). Soviet children had to learn to claim these freedoms without any attempt to enact them. They also should never claim the obvious reality of absence and active suppression of these freedoms. The following Soviet political joke of that time reflected this tension, "A [Soviet] kindergarten teacher conducts a guided discussion. She puts the World map on the wall and explains, 'Kids, this is the United States of America. People live badly there. They don't have money and that is why they don't buy candies and ice cream for their children and do not bring them to 
watch movies at theaters. But this is the Soviet Union. All people are happy here. They live well. They buy candies and ice cream for their children every day and bring them at theaters to watch movies.' Suddenly a little girl was crying. 'Why do you cry, Tanya?' asked the teacher. 'I want to live in the Soviet Union!' sobbed the little girl" (Bukovsky, 1979). Young Soviet children had to learn the indirect meaning and limits of the Soviet ideology, which created a need for the first sphere of performance of the official ideology without genuinely believing in or trying to enact it.

Third, the Soviet Communist ideology declared the absolute truth for all time and all people but it was also a subject of constant change by the current Communist leadership. Totalitarian dogmatic monologism does not tolerate any ambiguity and a possibility for change (Bakhtin \& Emerson, 1999). Totalitarianism - the total ideology - does not only create the total monopoly on the ideological space (i.e., topic diversity) but also on the ideological time (i.e., possible unpredictable changes). Public noticing of these ideological changes was dangerous. However, ignoring the changes was also dangerous. Children had to learn both to notice and to ignore the ideological changes at the same time. They had to accept unconditionally the new absolute truth without any focus on contradictions between its novelty and absolutism. As an old Soviet joke goes, "One is applying for a job and he has to answer to the following question on the job application form, 'Have you ever deviated from the Party line?' One replies wisely, 'Yes, I have deviated but only together with the Party."' In a few months after the General Secretory of the Communist Party Leonid Ilich Brezhnev died, high school students in the school I taught were asked to cross out certain sentences in their history and literacy textbooks (King, 1997). As far as I remember, the teachers did not provide any explanations to their request, as if it were a conspiracy, in which the students also actively participated. "In the Soviet Union there is nothing more unpredictable than its past" (a popular Soviet joke, Ivanova, 2000, July). The changes in the Soviet totalitarian ideology pressed Soviet children to develop the first and second spheres of their consciousness: performative (the first consciousness) and critical (the second consciousness).

Fourth, Soviet children noticed and discussed discrepancies between Soviet officials' ideological claims and these officials' own actions (and Soviet reality), which prompted the development of the second sphere of critical private political consciousness. I remember when I was 10 , my peers and I noticed that our local Communist activist in our home building forced everybody to attend a subbotnik (a Communist "labor holiday" on certain Saturdays with mandated "volunteering" of labor for "a community"), while she never worked herself on a subbotnik. When I shared this observation with my parents, they replied that Communist leaders had more important organizational duties than the physical labor of commoners (like me). I counter-argued that Grandpa Lenin participated in the first subbontik in 1920 as a common physical laborer despite the fact that he was the head of the Soviet state and the Communist Party - the picture of him carrying out a huge log was hanging in my school (see Picture 2). My parents told me to stop talking dangerous rubbish because the current time was different from Lenin's time. From their reply and nonverbal tone of a mixture of anger at and fear for me, I realized that I was right but the truth of revealing the Party's hypocrisy was dangerous. This and other instances taught me the self-discipline of silence and recognition of contexts and participants with whom I could safely share my critical observations, which promoted the development of the second sphere of private critical consciousness.

Fifth, finally, it was a carnivalistic culture of ubiquitous political (and non-political) jokes that promoted the second, critical, sphere. Soviet carnivalistic culture introduced role flip-flops and ambivalence unknown to the serious monologic official certainty (cf. Bakhtin, 1984). This carnivalistic culture created intimacy, camaraderie, good laughs, and networks of support, in the context of a poor quality of public institutionalized services, deficits, or absence of some necessary institutions all together (e.g., banks). Political jokes rapidly spread over 12-hour time zones of the Soviet Union in a few weeks through face-to- 
face communication as telling them on wiretapped phones was dangerous. Political jokes were told in all strata of the Soviet Union, including Party and KGB bosses and children. Soviet-born journalist and historian Arkady Ostrovsky argued, "While the Soviet system still barred private ownership of land and property, it allowed [in the Soviet post-totalitarianism] space for privacy, for intimate feelings and thoughts" (Ostrovsky, 2015). In my view, "allowed" is a too strong word. The Soviet post-totalitarian officialdom tolerated, rather than permitted, the space for privacy, for intimate feelings and thoughts, under certain tacit norms and rules. These tacit rules involved the participants' visible attempts to keep their feelings and thoughts private, limited only to a small intimate group of confidants, and try not to enact these feelings and thoughts in public.

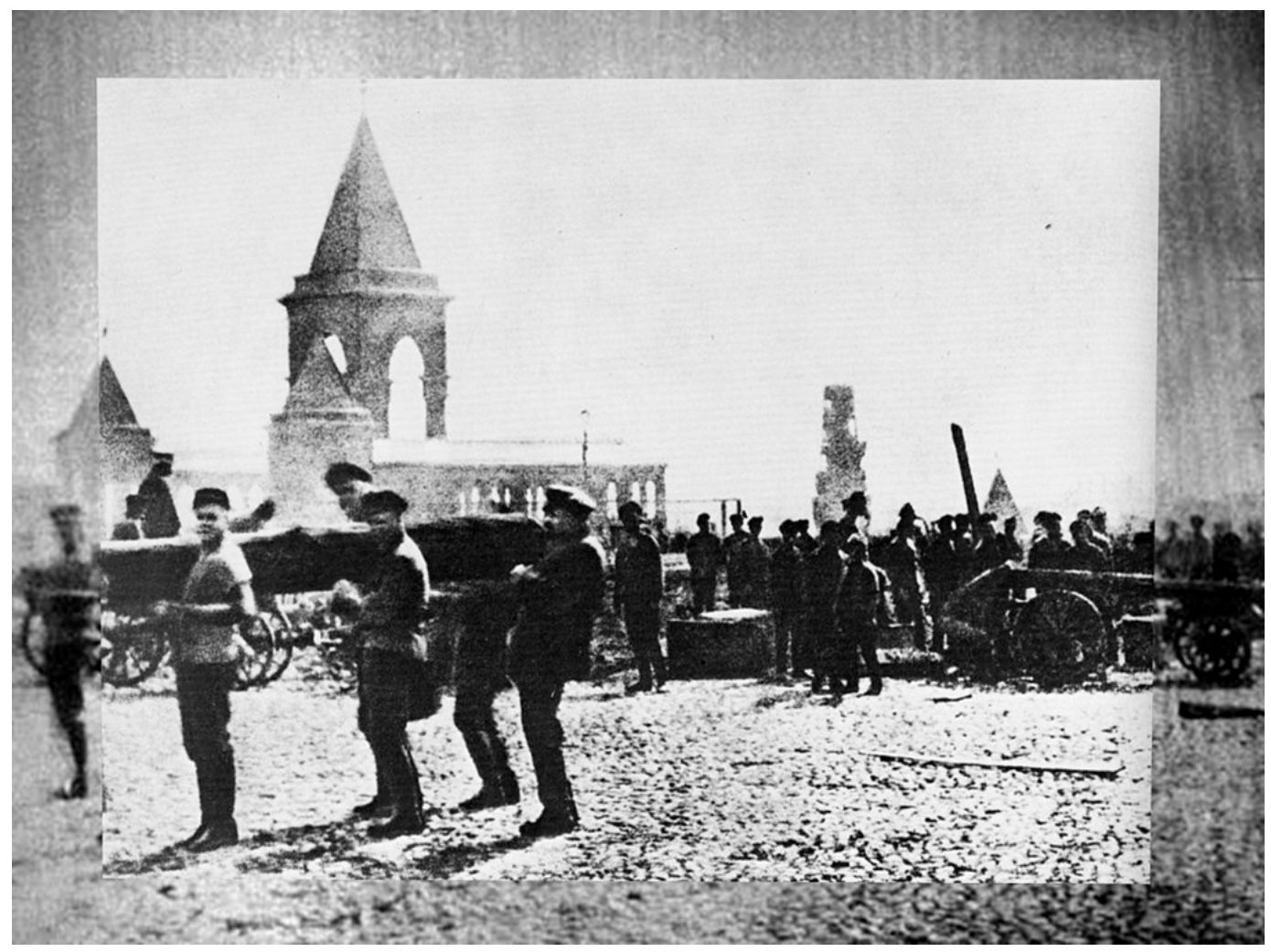

Picture 2. Vladimir Lenin (the man on the right), the Communist Leader, helps to carry a log during the first subbotnik, Moscow, 1920 (http://en.wikipedia.org/wiki/Subbotnik\#/media/File:19200501-lenin_subbotnik_kremlin.jpg)

Children heard political jokes from their parents, neighbors, siblings, and peers and passed them privately to their friends. The culture of political jokes was the collective, public, unofficial, critical political consciousness in the Soviet Union ${ }^{12}$. Being an audience of a political joke meant a sign of trust and inclusion. Here is my favorite political joke when I was 10 or 11, "In the morning, Brezhnev comes on his balcony, looks at the east, and greets the sun, 'Good morning Little Sun!' 'Good morning, dear comrade Leonid Ilich!' - replies the sun. In the noon, Brezhnev comes on this balcony, looks up, and greets the sun, 'Good afternoon, Little Sun!' 'Good afternoon, dear comrade Leonid Ilich!' - replies the sun. In the evening, Brezhnev comes on his balcony, looks forward, and greets the sun, 'Good evening, Little Sun!' The sun keeps silence. Brezhnev repeats, 'Good evening, Little Sun!' The sun finally replies, 'Fuck off, Brezhnev,

\footnotetext{
12 That is why my personal memoirs are full of many Soviet political jokes. They are a part of my private critical consciousness.
} 
I'm already on the West!'”13 The participation in these political jokes required critical thinking and restraint - the necessary ingredients for the private critical political consciousness.

It seems to me that all of these five processes of Soviet children's ideological becoming, embedded in the official Soviet ideology propaganda, unavoidably pushed for the emergence of the triple consciousness in many Soviet children. The degree to which each of these spheres affected Soviet children varied, depending on the children's personalities, circumstances, culture, history, local politics, ethnicity, class, parents' political attitudes, and social surroundings. One of the consequences of this emergence of the triple consciousness in the Soviet children was that they often became very savvy in recognizing what an authority wanted from them and were able to feed the authority with what they wanted to hear from them. This skill was well articulated with the following Soviet joke, "If you're my boss, I'm your fool. If I'm your boss, you're my fool." I remember in the early 1990s, a West German scholar visited the University of California at Santa Cruz where I was doing my PhD in developmental psychology. At an informal lunch, he shared with me that it was almost impossible to study East German kids (it was immediately after reunification of East and West Germany). In contrast to West German children who tried their best to share with the researchers what they thought when asked on a survey, East German children, raised under a socialist regime, tried to guess what the researchers wanted them to say and to please them. The West German psychologist complained that in the case of East German children, he studied not what the Eastern German teens thought, but their perception of his desires. Teaching in the US, I have been surprised again and again how American students are not aware of potential social danger of information they may freely reveal about themselves to me, their teacher. However, children from socialist countries often developed a deep distrust to authority that I will discuss in my section on schooling.

\section{Growing in the Soviet Post-Totalitarian Nationalist Socialism as a national minority: The marginal consciousness}

At the beginning of the Nazi German invasion of the USSR in the summer of 1941 (during the WWII), Stalin abruptly shifted the official Soviet ideology from International Communist to Nationalist Communist. The Soviet anthem was changed from the International ("'Tis the final conflict/ Let each stand in his place/ The International Union/ Shall be the human race") to the anthem worshiping Great Russia, "Unbreakable Union of freeborn Republics,/ Great Russia has welded forever to stand./ Created in struggle by will of the people, / United and mighty, our Soviet land!" If before the 1940s, peoples (e.g., Kazakhs, Ukrainians, Estonians) were purged and oppressed according to "the class principle", now they became purged and oppressed according to a purely national principle. Thus, some peoples, like Chechens and Crimea Tatars, were announced "peoples-traitors" and exiled to Kazakhstan (and killed and sent to Gulag) (Snyder, 2010). Jews were denounced as "cosmopolitans" and were prepared for sanctioned pogroms and exile to Siberia, where "the autonomous Jewish region of Birobidzhan" was created (Solzhenitsyn, 1974a). Russian chauvinism grew. For example, all major great scientific and technological discoveries were attributed to Russian inventors and scientists (which was reflected in school science textbooks) ${ }^{14}$. Arguably, Russian nationalism and chauvinism was a crack on the Soviet International Communist totalitarianism of the Stalinist and post-Stalinist era rather being well incorporated into the Communist totalitarianism itself. The nationalism was not openly and clearly incorporated into the Soviet official ideology, remaining an officially-unofficial shadow ideology and practice. Nationalism promoted the marginal consciousness manifested in many Soviet minority citizens.

\footnotetext{
${ }^{13}$ Interestingly, a similar joke about then General Secretary of the East German Communist Party Erich Honecker was told in the 2006 German movie "The lives of others" (http://www.imdb.com/title/tt0405094/).

${ }^{14}$ Popular jokes of those years was that "the horse neigh was invented in Russia" or "Russia was the motherland of all elephants."
} 
Table 1. Types of observed political consciousness in the Soviet Union

\begin{tabular}{|c|c|c|c|c|}
\hline $\begin{array}{l}\text { Types of } \\
\text { consciousness }\end{array}$ & Description & $\begin{array}{l}\text { Relationship to the } \\
\text { officialdom }\end{array}$ & $\begin{array}{l}\text { Relationship } \\
\text { to the self }\end{array}$ & Examples \\
\hline $\begin{array}{l}\text { 1. Performative } \\
\text { political } \\
\text { consciousness }\end{array}$ & $\begin{array}{l}\text { Performance of } \\
\text { loyalty to the } \\
\text { official ideology }\end{array}$ & Officially sanctioned & Insincere & $\begin{array}{l}\text { Official } \\
\text { ceremonies }\end{array}$ \\
\hline $\begin{array}{l}\text { 2. Critical political } \\
\text { consciousness }\end{array}$ & $\begin{array}{l}\text { Private critical } \\
\text { beliefs about the } \\
\text { totalitarian } \\
\text { regime }\end{array}$ & $\begin{array}{l}\text { Passive opposition } \\
\text { without action, } \\
\text { tolerated by the } \\
\text { officialdom to a point }\end{array}$ & $\begin{array}{l}\text { Sincere but } \\
\text { compromised }\end{array}$ & Political jokes \\
\hline $\begin{array}{l}\text { 3. Fanatical } \\
\text { political } \\
\text { consciousness }\end{array}$ & $\begin{array}{l}\text { Private sincere } \\
\text { beliefs in the } \\
\text { regime }\end{array}$ & $\begin{array}{l}\text { Officially promoted but } \\
\text { not sanctioned, } \\
\text { tolerated by the } \\
\text { officialdom to a point }\end{array}$ & $\begin{array}{l}\text { Sincere and } \\
\text { uncompromis } \\
\text { ed }\end{array}$ & $\begin{array}{l}\text { Private political } \\
\text { initiatives in } \\
\text { accord with the } \\
\text { official ideology }\end{array}$ \\
\hline $\begin{array}{l}\text { 4. Underground } \\
\text { political } \\
\text { consciousness }\end{array}$ & $\begin{array}{l}\text { Private and } \\
\text { communal active } \\
\text { opposition to the } \\
\text { regime }\end{array}$ & $\begin{array}{l}\text { Active but } \\
\text { compromised } \\
\text { opposition with action, } \\
\text { civil disobedience, non- } \\
\text { participation, tolerated } \\
\text { by the officialdom to a } \\
\text { point }\end{array}$ & $\begin{array}{l}\text { Sincere but } \\
\text { compromised }\end{array}$ & $\begin{array}{l}\text { Internal } \\
\text { emigration, } \\
\text { participation in } \\
\text { political and non- } \\
\text { political } \\
\text { underground } \\
\text { movements and } \\
\text { black market }\end{array}$ \\
\hline $\begin{array}{l}\text { 5. Dissident } \\
\text { political } \\
\text { consciousness }\end{array}$ & $\begin{array}{l}\text { Open political } \\
\text { opposition to the } \\
\text { regime by "living } \\
\text { in truth," united } \\
\text { consciousness }\end{array}$ & $\begin{array}{l}\text { Active uncompromised } \\
\text { resistance, not } \\
\text { tolerated by the } \\
\text { officialdom }\end{array}$ & $\begin{array}{l}\text { Sincere and } \\
\text { uncompromis } \\
\text { ed }\end{array}$ & $\begin{array}{l}\text { Open dissident } \\
\text { movement }\end{array}$ \\
\hline $\begin{array}{l}\text { 6. Marginal } \\
\text { consciousness }\end{array}$ & $\begin{array}{l}\text { Underground } \\
\text { official ideology }\end{array}$ & Unofficially sanctioned & Split & Nationalism \\
\hline $\begin{array}{l}\text { 7. Agentic } \\
\text { consciousness }\end{array}$ & $\begin{array}{l}\text { Unconditional } \\
\text { following the } \\
\text { authority, } \\
\text { regardless } \\
\text { personal } \\
\text { conviction }\end{array}$ & $\begin{array}{l}\text { Promoted, justified, } \\
\text { imposed, and } \\
\text { sanctioned by the } \\
\text { officialdom }\end{array}$ & $\begin{array}{l}\text { Unconditional } \\
\text { submission to } \\
\text { the will of } \\
\text { authority }\end{array}$ & $\begin{array}{l}\text { Functionary in } \\
\text { the bureaucracy }\end{array}$ \\
\hline $\begin{array}{l}\text { 8. Camaraderie } \\
\text { consciousness }\end{array}$ & $\begin{array}{l}\text { Real horizontal } \\
\text { socialism }\end{array}$ & $\begin{array}{l}\text { Suspicion and distrust } \\
\text { of and by the } \\
\text { officialdom }\end{array}$ & $\begin{array}{l}\text { Sincere and } \\
\text { uncompromis } \\
\text { ed }\end{array}$ & $\begin{array}{l}\text { Adult and } \\
\text { children peer } \\
\text { culture }\end{array}$ \\
\hline
\end{tabular}

In the USSR, nationality meant one's ethnic origin and not citizenship or religion. Nationality was the fifth item in the Soviet internal passport. Nationality was reported in the classroom grade record book for teachers ("klassnyj zhurnal") but students were often able to get their hands on it and find out about their classmates' nationality (along with other things). Also, children and adults learned and were socialized through nationalist discourse to recognize patterns ${ }^{15}$ of non-Slavic nationalities by people's faces and skin

\footnotetext{
${ }^{15}$ I suspect (i.e., hypothesize) that this process of learning ethnic faces through discursive pattern recognition in the Soviet Union (and modern Russia) might be similar to learning "talking science" in school described by Jay Lemke (1990).
} 
color. Non-Russian people were often referred by their nationality (e.g., Tadjik Kostya, Gypsy Masha). Of course, people made mistakes from time-to-time but it did not preclude them from trying again. As a teen and an adult, I was frequently recognized by strangers as being a Jew by my "typical Jewish face." This recognition was often Gestalt-like (i.e., holistic and impressionistic), without any conscious trait-like analysis of a facial stereotype (but not always).

I learned about Anti-Semitism and other nationalistic slurs before I learned that I was a Jew by nationality. My peers and adults around me often used these nationalistic slurs. As a little child I knew that they meant bad things but not necessarily as relevant to nationalities. For example, as 5-year old, I was using the phrase "ne zhidish ${ }^{16}$ !" which I meant "share, don't be a scrooge!" but literally it meant "don't be such a Kike!" - an Anti-Semitic slur implying that all Jews are cheap, selfish, and not generous. As a child, I commonly used the nationalistic slur "tsyganit" meaning "to aggressively beg for money" - the word originated from "tsygan" (Gypsy, Roma people, in Russian). As young children, we commonly used nationalistic slurs against Russians ("katsap") and against Ukrainians ("khokhol") and against many indigenous people ("churka") without necessarily knowing the nationalistic and chauvinistic nature of these words. There were many nationalistic and chauvinistic jokes circulating in the Soviet Union (e.g., see Chukchi [an indigenous Siberian people, kin to American Alaska Inuit] Soviet distasteful nationalistic jokes here: http://www.vavpages.narod.ru/eng/chuckcha.htm portraying Chukchi people as stereotypically stupid, primitive, and without a refined culture). In my observation, Soviet nationalism and chauvinism was an organic and monolithic part of the Soviet consciousness. Even many (but not all!) of the famous Soviet dissidents were national chauvinist (e.g., Igor Shaferevich http://en.wikipedia.org/wiki/lgor Shafarevich, renown dissident writer and the Nobel prize winner Alexander Solzhenitsyn). It is true that the official Soviet Communist propaganda emphasized "internationalism", "class international solidarity," and "friendship of peoples" but at the same time it officially promoted Great Russia chauvinism and especially after WWII, the Soviet Socialism became nationalist rather than internationalist in its nature. The internationalismnationalism was a serious internal contradiction of the Soviet official ideology that threatened to split ideologically the totality of the Communist totalitarianism ${ }^{17}$. A complication of this development was a proliferation of non-Russian and anti-Russian nationalisms (and/or chauvinisms) in the Soviet Union that became oppositional to the Soviet totalitarianism and was under assault by the regime ${ }^{18}$, and thus penetrated multiple consciousness in the Soviet Union.

I learned that I was a Jew from my parents when I was nine. I was telling my parents about my daily school events when accidentally I called one of my (Russian) classmates a "zhid" for not willing to share his toy with me and other classmates. My parents were openly upset and asked me not to use this word. I asked them why. They explained to me that this word means "a Jew." I replied, "So what?! Everyone knows that Jews are greedy!" And I was told that I and all my family were Jews and we, like many other Jews, were not greedy. Soon I started experienced Anti-Semitism against myself. A grandma of one of my classmates, who was a Pole by nationality, did not allow him to play with me because I was a Jew. I remember her saying to her grandson while pointing at me, "Don't play with Jews. They're very treacherous!" I did not want to be a Jew because I had known that Jews were "dirty," "greedy," and

\footnotetext{
${ }^{16}$ The Russian racial slur "zhid" comes from a colloquial and conventional Polish word meaning "Jew" (the Polish word has the same origin as the English word - "Judea"). But in Russian this word became a slur. In Russian, a neutral conventional word for "Jew" is "evrey" coming from the word "Hebrew" (like in Italian "ebreo"). This seems to be a similar transformation for the English-American word "Negro" (meaning "black" in Spanish) that historically became racial slur and has been replaced with the neutral English word "Black."

17 In the 1970s, the informal Russian national chauvinistic movement "Pamyat"' (Memory) emerged in the USSR and the Soviet authorities did not know how to respond to this non-official, non-sanctioned but officially tolerated movement http://en.wikipedia.org/wiki/Pamyat.

${ }^{18}$ Studying national languages (e.g., Yiddish, Hebrew) and cultures was an official crime punished by imprisonment in Gulag in the USSR.
} 
"treacherous" as my Russian and non-Russian friends, peers, and adults told me on many occasions. But, I did not have a choice. Once in 6th grade, a Russian boy who did not like me (we openly called each other "enemies") came to my Russian friend and told him that I was a Jew. My Russian friend did not believe him, turned to me, and asked, "He said that you're a Jew! Are you?!" I replied with sarcasm, "Oh, yeah! I am a Jew." Both of them were satisfied with my "treacherous" answer: my Russian friend could hear my sarcasm, challenging the accusation, but my Russian enemy could only hear my confirmation of his accusation. My Russian friend conspiratorially smiled at me and replied in sarcasm to my Russian enemy, "Yeah, I knew it all the time!" My Russian enemy was surprised and disappointed that he could not break our friendship he exclaimed, "You're both zhids [Kikes]!" and moved away from us. Thus, I kept my friendship. However, I wasn't happy about it -- I knew that I was betraying myself and my family. I was able to solve the problem of keeping my Russian friend at the expense of splitting my own consciousness. Looking back, I have noticed that almost all my school friends, with some minor exceptions, were non-Russians: Tatars, Ukrainians, Poles, and Jews. I guess there was both centrifugal and centripetal nationalist forces that shaped our child friendships.

Soviet nationalism generated an additional double-consciousness that is similar to one described by W.E.B. Du Bois (1961), and by Russian nineteenth century fictional writers Gogol and Dostoevsky in their stories and novels, analyzed by Bakhtin (Bakhtin \& Emerson), and by Kurt Lewin (1948). Lewin referred to it as the marginal consciousness. The marginal consciousness is different from other multiple consciousnesses that I observed in the Soviet Union because it is not just double-consciousness but rather a split consciousness. In other words, all other multiple consciousnesses that I noticed in the USSR and described here manifested themselves in certain situational domains. Thus, my school principle, described above, might show her critical consciousness in one situation, while her performative consciousness in another. Her consciousness was situation-specific - within one situation, my principal's consciousness was single and not multiple. In contrast, the marginal consciousness, described by Du Bois, Gogol, Dostoevsky, Bakhtin, and Lewin, had internal multiplicity that penetrated the consciousness itself, regardless of the situation. Marginal people became walking problems for others and themselves, without having a reliable community behind (Matusov, 2009). Soviet nationalism made minority people a problem to be solved, in a similar way American racism made Blacks a problem to solve:

Between me and the other world there is ever an unasked question: unasked by some through feelings of delicacy; by others through the difficulty of rightly framing it. All, nevertheless, flutter round it. They approach me in a half-hesitant sort of way, eye me curiously or compassionately, and then, instead of saying directly, How does it feel to be a problem? they say, I know an excellent colored man in my town; or, I fought at Mechanicsville; or, Do not these Southern outrages make your blood boil? At these I smile, or am interested, or reduce the boiling to a simmer, as the occasion may require. To the real question, How does it feel to be a problem? ${ }^{19}$ I answer seldom a word.

... After the Egyptian and Indian, the Greek and Roman, the Teuton and Mongolian, the Negro is a sort of seventh son, born with a veil, and gifted with second-sight in this American world,a world which yields him no true self-consciousness, but only lets him see himself through the revelation of the other world. It is a peculiar sensation, this double-consciousness, this sense of always looking at one's self through the eyes of others, of measuring one's soul by the tape of a world that looks on in amused contempt and pity. One ever feels his two-ness, - -an American, a Negro; two souls, two thoughts, two unreconciled strivings; two warring ideals in one dark body, whose dogged strength alone keeps it from being torn asunder (Du Bois, 1961, p. 16).

${ }^{19}$ Unfortunately, more than 100 years later, minority students are still seen as "a problem to deal with" by some teachers in the US as the incident described above reveals. 
Minority people became marginal people whose voice and loyalty was constantly challenged by both the officialdom and common majority people (and even other minorities). Lewin analyzed uncertainty of belonging that was especially troublesome for privileged minority people:

Not the belonging to many groups is the cause of the difficulty, but an uncertainty of belongingness.

In practically every underprivileged group a number of people will be found who, although regarded by the privileged majority as not belonging to them, feel themselves not really belonging to the underprivileged minority. Frequently it is the more privileged people within the underprivileged group, or those people whose open or secret intent it is to pass the line, who are in the position of what the sociologists call "marginal men." They are people who belong neither here nor there, standing "between" the groups. The psychological difficulties which the marginal man has to face-his uncertainty, his instability, and often self-hate, due to the more or less permanent state of conflict in which he finds himself-are well known to the student of sociology.

The frequency of "marginal" persons in an underprivileged group is likely to increase the more the differences between the privileged and underprivileged groups decrease, with the resulting paradox that the betterment of the group might increase the uncertainty and tension of the individual (Lewin, 1948, pp. 179-180).

The acme of my personal experience with Soviet state-sponsored Anti-Semitism occurred when, after graduation from my high school that specialized in math, I applied to Mekh-Mat ${ }^{20}$ at MGU (or MSU in English, Moscow State University). I applied for Mekh-Mat in 1977 and failed on the written math exam, which was the entrance exam in Mekh-Mat. As a Jew, by 17, I had known quite a lot about the Soviet State Anti-Semitism but I wanted to make sure that I really had no chance of joining MGU and all doors were closed for me as a Jew. My parents and relatives tried to dissuade me from applying to MGU expecting a big personal trauma for me but I insisted. I expected to fail a Russian essay exam because literature and composition were subjective and ideological and thus easy to manipulate. The oral math exam was also a possibility because it did not leave paper traces (Shifman, 2005). However, I was surprised to fail a WRITTEN math exam, for math being an "exact" science and a written exam was leaving paper traces.

I was well prepared in math by my Moscow math specialized school 91 (Matusov, 2017). All my non-Jewish classmates entered MGU and other exact science-oriented colleges without a problem. But not ALL Jews. I had numerous awards from math contests ("Math Olympics") organized by the city and various colleges, including MGU.

I was shocked to learn that I failed the WRITTEN math exam. I believed that I fully solved four math problems out of the five presented and I was half way through the fifth. I compared my solutions with my non-Jewish classmates, who were later accepted to the Mekh-Mat and my solutions were on par with theirs (some did better and some worse than me on the exam in our analysis).

I decided to appeal to see my scored work with my own eyes and to question the scores. I naively thought that math was math even in such a racist nationalistic country as the USSR. I was wrong. At the same time, a voice of doubt ate away my soul: what if I was not as good at math as I thought?! As Du Bois and Lewin argued this anxious voice of doubt, constantly undermining one's marginal existence, is the birthmark of painful split-consciousness caused by racism and nationalism (and classism in the case of the $19^{\text {th }}$ century Tsarist Russian Empire described by Gogol and Dostoevsky).

\footnotetext{
${ }^{20}$ The Mechanico-Mathematical major.
} 
As soon as I arrived at the appeal process, Jews were separated from non-Jews using our Soviet internal passports with the fifth question about "nationality." Given that my passport nationality was "evrey" (Jew in Russian), I joined all other Jews in one room while all non-Jews were directed to different rooms for their appeal.

When my turn came, I was invited in and placed at a desk between two big guys in their late $30 \mathrm{~s}$. When one asked a question and I started thinking about an answer, the other guy asked another question, which distracted me from the first question (and I was understandably nervous in the first place). As soon as I started replying to the second guy, the first guy interrupted me and told me, "You see, you cannot answer on any of our questions." In general, they tried to convince me that: a) I did not know math, b) I had low intelligence in general, and c) I had low moral integrity since only by cheating I could have gotten all these excellent academic records. For the latter, they used a tacit argument that being a Jew, I probably bought my awards for math contests and my good school grades, since I was obviously was poor in math (see, Frenkel, 2013; Shifman, 2005, for description and analysis of these systematic Anti-Semitic practices at MSU sanctioned by the Soviet State). Their strategy of psychological disbalancing and pressure was well-developed and well-applied. I felt like at a KGB interrogation (Frenkel, 2013). I had nervous breakdown after this experience (as my parents predicted).

But back to my scored exam work: I had "impure pluses" on all 5 math problems: plus-minus, plusdot, minus-plus (for the last problem that I knew I had not solved). "Impure pluses" meant that a problem was unsolved and was not counted (Shifman, 2005). Let me provide one example of a math problem that was scored as "plus-minus". It was a geometric problem involving a right-angled triangle. I wrote in my solution that, "According to the Pythagorean Theorem, the square of cathesis (a triangle leg) is equal to the square of hypotenuse minus the square of the other cathesis (leg)." The examiner crossed out my wording "according to" and replaced it with "from." My two interrogators at the appeal told me that: 1) I did not know the correct formulation of the Pythagorean Theorem and 2) I was not skillful in Russian enough to understand a sematic difference between "according to" and "from".

I remember a Jewish girl at a neighboring desk suddenly jumped from her place (sitting like me between two of her big guys) and yelled at them, "You will live in this shitty country, while I'll study at Sorbonne!" She then stormed out of the room. I think she was right about the racist Soviet Union being a "shitty country" and I hope that she managed to emigrate from the USSR ${ }^{21}$ to France and her dream of studying in Sorbonne became true.

My Jewish classmate from the Moscow math school 91, who got a $C$ for her written math MekhMat exam only to be failed in an oral math exam, emigrated from the USSR with her wise and brave parents in 1979 and she became a math professor in the US. Unfortunately, I had to wait for the next emigration wave in 1988 when the Soviet door again opened up to leave the racist country. In the US, I got my PhD in psychology and became a professor of education. I did not become a mathematician ${ }^{22}$. You can read a similar personal account from a now famous American mathematician Edward Frenkel, a Soviet Jew

\footnotetext{
${ }^{21}$ The emigration pathway for Jews was very difficult but open in the 1970s until the beginning of the Soviet invasion of Afghanistan started in the late December of 1979. It was reopened only in 1988 under Gorbachev, when I left the country.

${ }^{22}$ However, being in an engineering college that accepted Jews, I attended an underground university, Jewish People's University (JPU), taught by famous Soviet professors from MSU and other prestigious colleges (including some Russian and non-Jewish professors) who heroically resisted the Soviet State-sponsored Anti-Semitism. However, in July 1982, KGB cracked down on this underground university for Jewish students and one organizer, Bella Subbotskaya (https://en.wikipedia.org/wiki/Bella Subbotovskaya), was apparently assassinated in fall 1982. The other two organizers of JPU Valery Senderov and Boris Kanevsky were arrested, imprisoned and then exiled (Shifman, 2005).
} 
refugee like $\mathrm{me}^{23}$ (see also, Shifman, 2005, for detailed accounts of the entrance examination Soviet state Anti-Semitism).

\section{Soviet school: The agentic consciousness}

American psychologist Stanley Milgram defined "the agentic state" in the following way:

... the person entering an authority system no longer views himself as acting out of his own purposes but rather comes to see himself as an agent for executing the wishes of another person. Once an individual conceives his action in this light, profound alterations occur in his behavior and his internal functioning. These are so pronounced that one may say that this altered attitude places the individual in a different state from the one he was in prior to integration into the hierarchy. I shall term this the agentic state, by which I mean the condition a person is in when he sees himself as an agent for carrying out another person's wishes. This term will be used in opposition to that of autonomy - that is, when a person sees himself as acting on his own (Milgram, 1974, p. 147).

The agentic state studied by Milgram in democratic capitalist societies was like a fish out of water. Ideologically, a democratic society does not support agentic conformism. On the contrary, it promotes nonconformist individualism. And, still, to surprise of many people Milgram found that many people in democratic societies demonstrate an agentic state. In contrast, in the (post-) totalitarian Soviet Union, the fish was in the water. The totalitarian ideology and Soviet institutions actively supported the agentic state.

The agentic consciousness is somewhat similar to the performative political consciousness because in both cases a person enacts ideology, in which he or she may not believe or be committed to on his/her own. However, they are different at least in two accounts. First, the performative political consciousness is a deliberate political strategy that the person chose for his/her survival via performance of his/her political loyalty. Thus, Vaclav Havel described and analyzed why a Czech greengrocer would place a Communist slogan, in which he did not believe (Havel \& Vladislav, 1989). In contrast, in the agentic consciousness, any autonomous decision making is suppressed. Second, in contrast to the performative political consciousness, the agentive consciousness is not necessarily political or totalitarian in its nature.

In my reflective observation, Soviet school promoted both the performative political consciousness and the agentic consciousness. The former was achieved through many highly visible political rituals and participation in the young Communist organizations and activities. The latter was much more tacit and involved a special non-political ideology, involving non-individualistic homogenizing norms. "Do like everybody else!" Any deviation from the established norm was seen as a sick egoistic perversion by the person, who wants to be "above" the Soviet collective. This ideology was nicely captured by the Russian 2008 musical "Stilyagi," portraying Soviet underground hipster ("stilyagi ${ }^{24 ") ~ m o v e m e n t ~ i n ~ t h e ~ s e c o n d ~ p a r t ~ o f ~}$ 1950s, in the following dialogue between female youth Communist leader, Katya, and her male friend, Mel, who became a stilyaga, i.e., a hipster, (both were college students),

Katya: I just want to know, what do you feel when people look at you that way [i.e., having a fashionable colorful dress and a hairstyle very uncommon in the Soviet Union in the mid 1950s]?

Mel: It's fun!... It's great, Katya, when all people are different. I'm like this. She's like that. And you are completely different.

Katya: I don't want to be different.

${ }^{23} \mathrm{http}: / /$ www. newcriterion.com/articles.cfm/The-Fifth-problem--math---anti-Semitism-in-the-Soviet-Union-7446

${ }_{24}$ The Russian word "stilyagi" is derogatory, comes from the word "style" to reflect Soviet hipsters interest in dress fashion https://en.wikipedia.org/wiki/Stilyagi 
Mel: Why?

Katya: Because I don't think I'm better than other people.

Mel: It's not about being better or worse, but just different! Do you understand?

This non-political conformist ideology of being the same as everybody else under constant judging looks by normative others prepared Soviet students for the agentic state and the agentic consciousness. Agentic consciousness was a hidden curriculum of the Soviet school.

In my view, any conventional school based on making students arrive at preset curricular endpoints, mostly promotes an agentic consciousness. Conventional school often forces students to do assignments that are meaningless for the students, which they would not do on their own. Even more, conventional school disciplines many students to learn how to force themselves to accomplish unconditionally and unquestionably the activities assigned by other people. In my first grade, for some reasons I escaped the school agentic consciousness by populating my assigned homework and class work with my playful fantasies that were very meaningful for me personally. Many exercises in Russian (writing) involved completing sentences by filling in the omitted words marked with three dots. In my fantasy when I was in the first grade, I envisioned a little walking man, going over words in a sentence, only to face a river or a ditch marked by the three dots. Like the little man, I was thinking, what to do - how to cross the dots. I draw beautiful bridges over the three dots in my textbook or imagined swimming across. I loved my school. I loved doing homework - I joyfully spent many hours doing my exercises. I loved getting bad grades because I loved how my teacher drew her 2s (a failing mark grade corresponding "D") with all her love that looked to me like a beautiful red swan, swimming on a lake. For me, the well-rounded mark grade 3 ("C") looked much more appealing than the angular 4 ("B") or the arrogantly bragging 5 ("A"). I liked to collect as many red swans as possible. At times in my pleasant anticipation of the teacher's red swan, I carefully drew my own big blue swan after my home or class assignment. The teacher crossed out my blue swan with her angry strokes and drew her red swan next to mine (I admit hers was always more beautiful than mine). My mother was hysterical at my optimism bordered with idiotism when I joyfully announced getting another swan. She was crying and saying why I would not be ashamed of bad grades as all other kids. She always referred to my older brother who once buried his grade record book ("dnevnik") in the yard to hide getting bad grades (a neighbor found it and gave to my parents). She said that it was bad what my older brother did but she said it was more understandable than me being happy of getting bad grades.

When we moved to another apartment, in another district of Moscow, and I joined my second grade in another school, I got school broken. I started doing all school assignments without playing my fantasies. I started hating my school. I did my homework docilely, trying to spend as little time as possible on it. I became ashamed of bad grades. I obediently followed my teacher's order to search my peer to find out if he smuggled in school forbidden objects (e.g., toys, colorful wires, matches). I lost an ability to be an author of my life and became like other kids, at least, in school.

In my experiences and observations, Soviet school was highly regimented, highly normative, and highly conformist. Soviet teachers of the same grade and subject matter were supposed to be on the same page of the unified state-sponsored textbook across 12-time zones. Learning writing involved memorization of the grammar rules, a lot of dictation, some text summarizing, and some essay writing with the predictable endpoints - never self-expression. When I was a schoolteacher in the mid-1980s, there was a "big scandal" when one of high school students wrote in his exit exam essay that his favorite hero was Napoleon rather than an officially canonized Communist revolutionary martyr, as it was expected from him. Soviet students were expected to look the same, to act the same, and to think the same. The school required the agentic consciousness. Of course, in reality it did not always happen. At times, the normative homogenizing pressures were counteracted and actively resisted by the students' performative consciousness, by 
students' (and at times by teachers') underground consciousness of resistance, and by students' camaraderie consciousness that I am going to describe and discuss in this section.

Let me contextualize and exemplify the points above through analysis of my second-grade classroom (see the photo below):

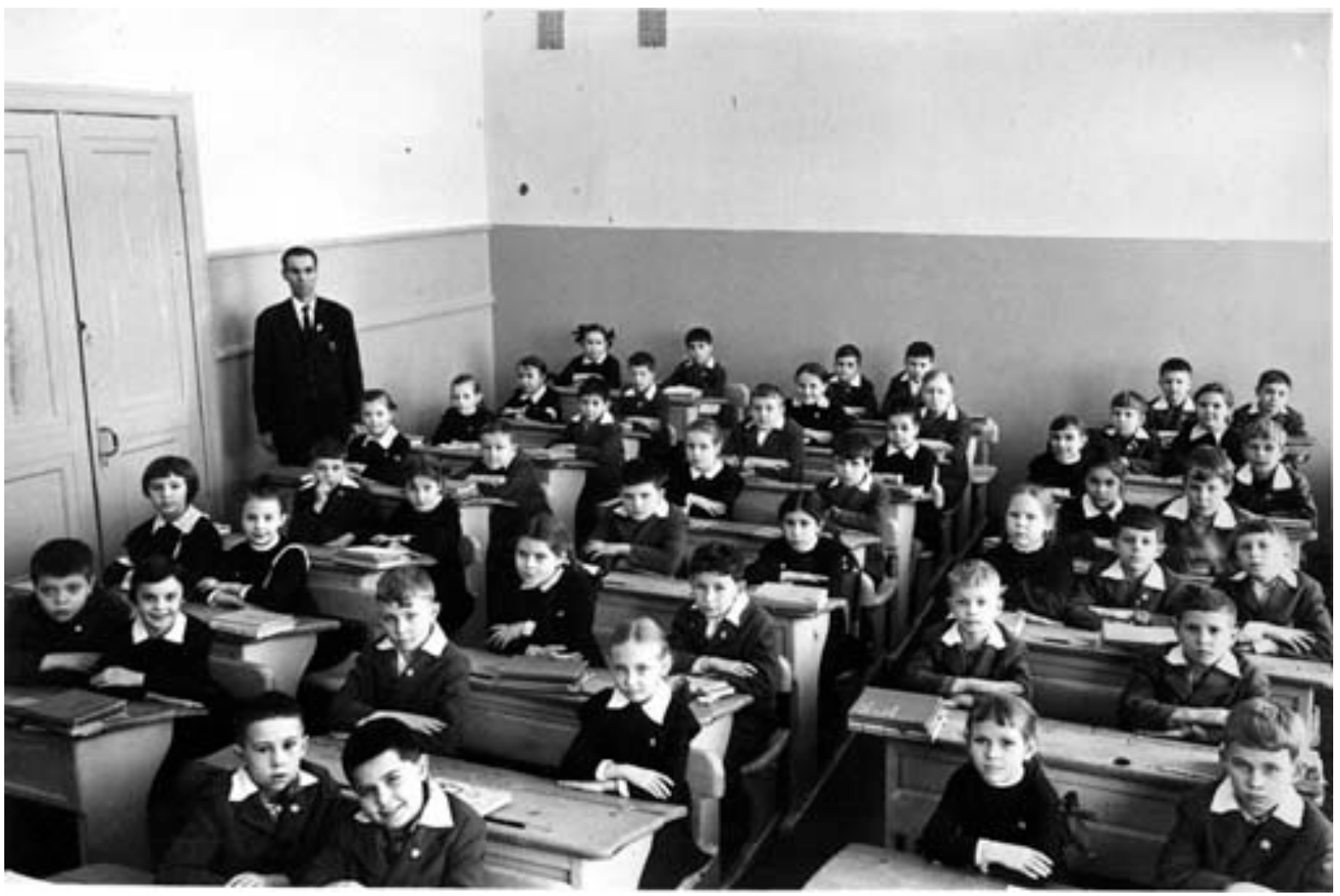

Picture 3. My second-grade classroom, Moscow, 1969 (photo from my personal archive)

In the photo, you see my 2nd grade classroom of Moscow school in 1969. Students are 8-9 years old. There were 48 students in the classroom. You can see only 45 students on the photo, three students were absent on the day of taking the picture. Because of the lack of desks, it was not uncommon for three students sitting at two-student desks. You can see three students sitting at one desk on the right row at the third desk. Not all Moscow schools were crowded as this one but it was not untypical school at this time as far as I know.

In the Soviet Union, elementary, middle and high schools were located in one building and were placed under unified school administration. Because of shortage of space some schools, like mine, were operating in two shifts. For example, in the school depicted on the photo, students from 1st and 5-10th grades attended school in the first shift starting at 8:30 am and ending about 2:30pm (depending on grade and number of lessons). Students from 2 nd to 4 th grades attended school in the second shift starting at $3: 30 \mathrm{pm}$ and ending about 7:30pm or later.

Students' desk placement in the classroom was the teacher's careful consideration. The teacher tried to tightly control the classroom to minimize unsanctioned communication among the students. Friends were not allowed to sit closer than at least one desk in between them. In the classroom above, friends were sitting at least two desks apart. You may notice that boys and girls were placed in the "checker" order again 
to minimize same-gender contacts among the students. On average, there were rather hostile relations among boys and girls, supported by the teachers' constant reminders of the contrasts and promotion of competitions between boys and girls (e.g., reprimanding a girl, "Dorokhova, why are you so clumsy, like a boy, in your cursive writing?!" - Soviet teachers addressed students by their last names; verbal, physical, and sexual harassment among students was common until high school, especially for girls who did not have a strong protective peer and sibling networks). The most problematic students (from the teacher point of view) were placed at the first desks (e.g., ones that smiled on the photo). Hands were supposed to be on the desk for the entire school day as you see (unless raised by the straight angle elbow to volunteer an answer). On the desks, students had to have a textbook, the report book ("dnevnik") where the teacher put current grades and notes for parents, a notebook, and a pen.

There were many other types of competitions that were promoted in Soviet schools that were often called "socialist competition", which was often but not always gendered,

The [Soviet pedagogical] manual begins with instructions for the teacher standing before the class on the first day of school:

It is not difficult to see that a direct approach to the class with the command, "All sit straight," often doesn't bring the desired effect since a demand in this form does not reach the sensibilities of the pupils and does not activate them.

In order to "reach the sensibilities of the pupils" and "activate them" according to principles of socialist competition, the teacher should say, "Let's see which row can sit the straightest" (Silberman, 1971, p. 129)

The class was divided onto several "Little Stars" with some formal structure set by the teacher. Almost all the 2nd graders (but not all) belonged to the Children of October Communist organization (you can see little pins on the students in the form of star with a picture of young Lenin in the center).

Forced collectivism, forced voluntarism, forced enthusiasm, and self-sacrifice in the name of a common good were a birthmark of the totalitarian Socialist Soviet society, leading among other things to the agentic consciousness. These totalitarian ideologies highly promoted in Soviet school socialized the children in fulfilling the will of other people automatically without questioning it, often overruling the children's own reluctance or concerns. Personal inclinations were intentionally suppressed. For example, all students (and adults) were supposed to engage in the "communal volunteer work/burden" (общественная работа, общественная нагрузка), which was mandatory despite its proclaimed voluntary nature. Initially, young elementary children were very enthusiastic about engagement in the communal "voluntary-mandatory" (добровольно-принудительная, a mock contradictory term informally and carnivalistically used in the USSR) work. Thus, I remember that in the first grade, my classmate and desk mate friend who was a girl and I decided to surprise our beloved teacher and our classmate by cleaning our classroom, in such a way that "cleanness would shine." Our parents found us at 9pm in the very messy classroom because our first stage of cleaning that somehow we did not pass for all the time was to expose the existing dirt and rubbish before cleaning it. My friend and I spent more time in dreaming about how our teacher and peers would appreciate our job than in actual cleaning. Our anxious, upset, and tired parents quickly cleaned the mess we created and escorted us home. Nobody praised for our "community work" or even noticed it. With time we became less and less enthusiastic and then even cynical about the community voluntary-mandatory work. The ethic of the community work reflected deep Soviet conviction that an individual had to sacrifice his/her pleasure, well-being, or even life for the good of the society. Pursuit of self-inflicted sacrificial suffering rather than happiness (cf. the US Constitution) was the right and obligation of all Soviet citizen. 
My wife still remembers being told by her first grade teacher, "Ryzhykh ${ }^{25}$, who said that you would be happy?!" Thus, the assigned communal work must be unpleasant for a student by the ideological agentic design. For example, if a student liked to draw or to write, he or she would not probably be assigned by the teacher to do a classroom wall newspaper ${ }^{26}$. This theme was very strong in Soviet movies and stories for children and adults. Tragic end rather than happy end was the norm, "The hero has died but his cause will prevail." Somehow, the contradiction between self-inflicted sacrificial suffering of each and happiness of all - an officially proclaimed goal of a Communist society - was not registered in the official Soviet ideology and apparently among many Soviet people.

The classroom on the photo above was ethnically diverse consisting mainly of Russians but also Ukrainians, Tatars, Poles, and Jews. Minority children were often verbally and physically harassed and abused by other kids (including other minority students). Some parents told children to distrust and to stay away from minority kids (e.g., "Don't play with them!" "Tatars are thieves and dirty," "Jews are cunning and treacherous") as I described in the section above. Parents of the students were either workers or college graduates (e.g., engineers). There was no much visible division among the children based on parents' education or type of their work, however, looking back I have reflected that fuzzy social class divisions might be evident in some older students' friendships (a systematic study is needed).

All Soviet students of my childhood wore uniforms (different for boys and girls). The school uniforms seem to reflect the societal aspiration of the children's future. The first Soviet uniforms appeared only in 1948 mostly copying tsarist school uniforms: soldier-like uniform for boys and maid-servant-like uniform for girls. During Khrushchev's era of the late 1950s - the early 1960s, the school uniform changed especially for boys, probably reflecting a change of official societal expectation for men - the school uniform for boys became more worker/laborer-like. Yet, in the mid-1970s, during Brezhnev's era, the school uniform changed again, especially for boys to become more bureaucrat-like. Arguably, Soviet school uniform represented the agentic standardization of the future Soviet citizens as the Communist Party wanted to see them (see the picture on the next page).

The agentic state was promoted both by the vertical hierarchies coming from our teachers and school administration and by the horizontal peer culture. These two sources of the agentic state were often (but not always) at odds with each other. The relationship between the teachers and students varied in Soviet schools but with older grades, it grew more and more distrustful. The teacher on the first photo was considered by the students (us) as "stern but fair ${ }^{27}$." Despite official prohibition of corporeal punishment by the Soviet law, he beat us with a steel metal or wooden ruler. He demanded our unconditional obedience (i.e., the agentic state) in exchange for his genuine care of us. When we transgressed his rules, we were supposed to stretch our hand palm up and he would hit us a few times by the ruler: it was painful but he did it without anger or sadism (as some other teachers did, who verbally or psychologically tried to abuse us). He served as a Soviet soldier during the WWII and had a severe concussion. He came from a peasant family and was proud to get higher education (you can see a college lapel pin, which was unusual among our urban college-graduate teachers). When he intercepted a note between two boys involving lyrics from

\footnotetext{
${ }^{25}$ My wife maiden last name. Soviet teachers referred students by their last names. Probably, because of that students often did not know their peers' first names and also referred their peers by their last names until they became very close friends.

${ }^{26} \mathrm{Cf}$., "'Public benefit' was exclusively defined as ideology-motivated activities. For a long time, I was handling the day-to-day running of the Leningrad (now St. Petersburg) Mathematical Society, a public organization dedicated to the advancement of science and independent of Leningrad University. According to rational thinking, this should be called public service; however, a university official told me: 'How can it be public service if, in fact, you enjoy it?"' (Vershik, 2005, p. 166).

${ }^{27}$ Ironically, this was people's qualifiers for Stalin.
} 


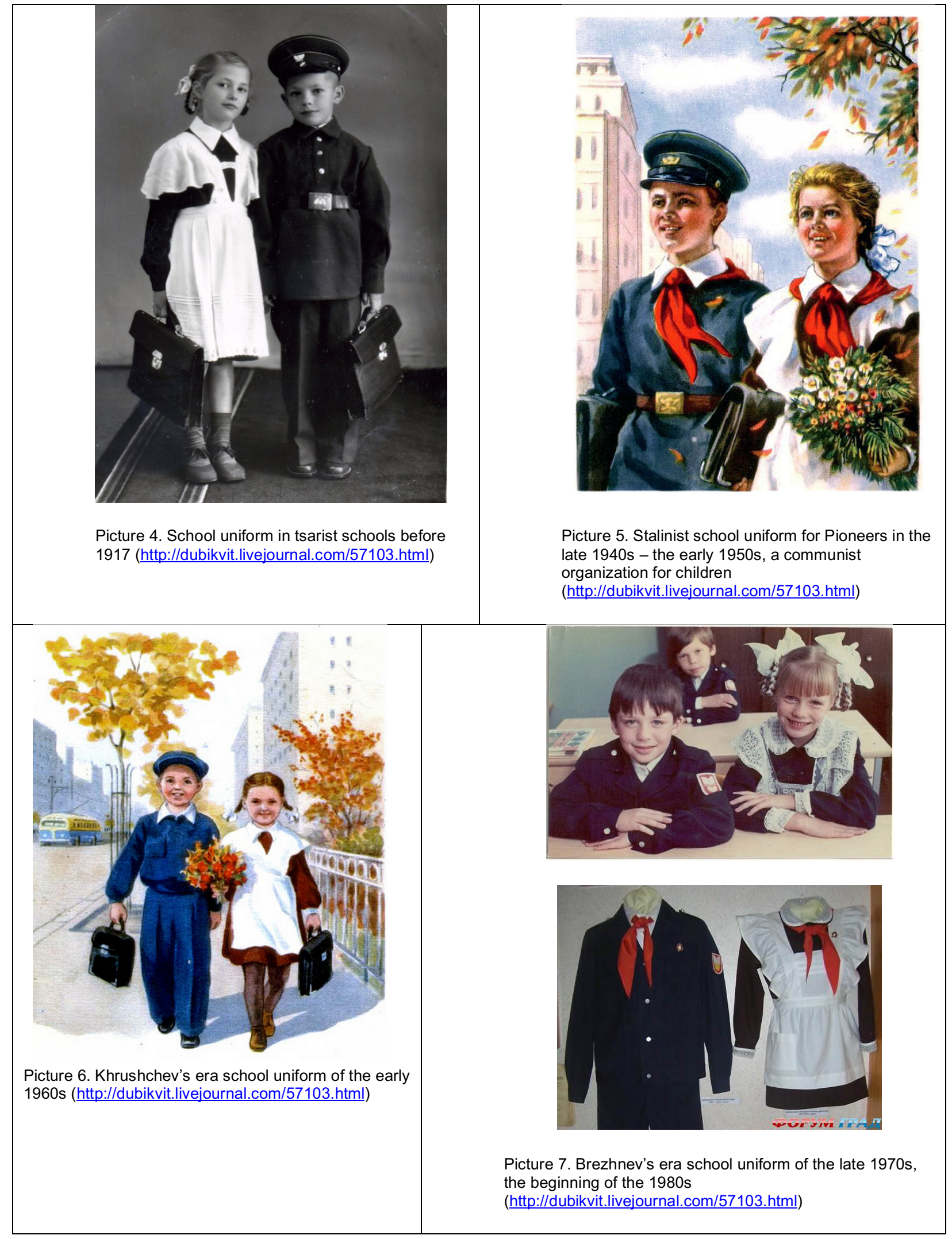


a song by then famous semi-underground Soviet bard and actor Vladimir Vysotsky ${ }^{28}$, he thoroughly searched our pockets, desks, and bags and visited homes of students' who had "Anti-Soviet lyrics" (including me) to talk to, reprimand, and threaten their parents (including my family). At the same time, he pedagogically advocated for me, strongly arguing against my retention in the $3^{\text {rd }}$ grade $-I$ could not read and barely could write because of my then-unidentified dyslexia. The teacher correctly argued that I would eventually overgrow this problem and my math learning was outstanding. Unlike some other teachers, he never involved the school administration in our problems and tried to be our advocate when we were in trouble with it. Also, I do not remember him exhibiting nationalism, nationalist favoritism or prejudices, in contrast to some other teachers.

It seems to me a part of the Soviet school unintended hidden curriculum was to teach students' animosity to at least some of their teachers as resistance to agentic imposition of the vertical authority of hierarchy. I have noticed that when Soviet school alumni meet, one of the popular topics is often a collective resistance, badgering, or even active humiliation of hated and unloved teachers. Usually, reasons for students' collective attacks on their teachers could be the teachers' dullness, feeblemindedness, injustice, bad temper, insensitivity, poor pedagogical quality, being boring, ill-intended, prejudiced, and so on perceived and/or experienced by the students. In my personal recollection, two of my high school teachers were special targets of our collective attacks. First was the teacher of Civil Defense. Despite his seriously looking uniform of a military officer (a major), he was pretty harmless, but perceived by us as rather stupid, dull, boring, and pedagogically inept. He delivered rather plain lectures about "American Imperialists and Militarists" and constantly threatened us with the Nuclear Holocaust. Being math and science savvy in our math specialized high school, we entertained ourselves by asking him technical and scientific questions, on which he did not know answers but did not want to admit it and provided us with ideological clichés that made us laugh. But we also made more serious pranks on him. Once, my male classmate brought a clock alarm and hid it under the teacher's desk. At the beginning of a regular boring lesson, we informed the teacher that American Imperialists placed a bomb in our class. Of course, he did not believe us. At some point of the lesson, we started counting backward from ten to zero, publicly announcing the explosion. But nothing happened (except our collective laughter). In ten minutes, we repeated the performance but this time the clock alarm went on. The teacher was rather scared as we theatrically and cruelly build the cathartic moment. On another occasion, some of my classmates launched a self-made black-powder jet rocket in his class. The rocket did not get up but fiercely danced on the floor exhorting huge stream of black smoke. The Civil Defense teacher tried to put it down by stepping on the rocket, which was not easy because the rocket constantly and unpredictably moved. When he managed to step down on the rocket, it moved up with new fury after he raised his foot off of it because in contrast to a typical fire, black power produced oxygen while burning and could not be extinguished when its access to external air was eliminated. We all knew that fact and the teacher's helplessness - interpreted as stupidity - entertained us a lot that day. We laughed to our tears, although some girls in our class thought that it was too much humiliation and they had pity at the teacher, until he went to complain to the school administration and their compassion evaporated.

In contrast to the Civil Defense teacher, the biology teacher was mean and ill-intended in addition to being pedagogically inept, boring, and not very knowledgeable about biology. She retaliated against students who knew biology better than her and promised to block their entrance to colleges by giving poor grade marks on the biology exit exam. Our counter-attacks were swift, creative, and cruel. I remember my classmate hiding behind the window curtain and booing time-to-time after we announced to the teacher that there was a ghost in our class. The poor teacher tried to find out who made the boo noise but she could not figure it out constantly blaming innocent students. She called our homeroom teacher (whom we respected) but the boos seized when our homeroom teacher was there and we pretended that we never heard the

${ }^{28}$ http://en.wikipedia.org/wiki/Vladimir_Vysotsky 
noise implying to our home teacher that the biology teacher lost her mind. On another occasion, we forced the biology teacher to dance after placing potassium iodine on the floor - when potassium iodine got dry it made popup explosion noises. The biology teacher liked to move during her lecture and popping sounds followed her.

Of course, we were often punished for our teacher-humiliation pranks by the school administration. But we had the unwritten $3 \mathrm{~N}$ rule: Never report on classmates who made a prank; Never reveal his/her name under school administration interrogations; and Never blame the prank ring-leader for a collective punishment however harsh it was. Reporting to the authority was a strong social taboo that was probably deeply rooted in the Soviet historical memory of the Stalinist purges. When I became a Soviet schoolteacher myself, I realized that many Soviet teachers knew about this social taboo among students and supported it. I remember talking with my young female colleague - an elementary school teacher - during a recess, when her 3rd grade student came to her to complain at a classmate who violated the teacher's rules. My colleague apologized to me and left for a while to punish the rule offender. When she came back, she told me that she would "strike back" at this "little stoolpigeon" («стукачок» ${ }^{29}$ ), the child who made the reporting, as well later on. When I asked her why she would do that, she replied, "Today this little jerk reported on his classmate - tomorrow he will report on me. He needs to be taught a lesson." The historic memory of the Stalinist purges, where a neighbor reported on a neighbor, a friend on a friend, children on parents, and so on seemed to become imprinted in Soviet educators and students. When my son, who grew up in the US, visited my college in Russia with me in 2002, he was shocked how Russian college students openly prepared for a collective cheating on their exam, ignoring us, strangers, passing by. My son was surprised that the students were not afraid of us who might report on them to the authority. This idea never crossed my former Soviet mind, as it was culturally and historically unthinkable.

The student solidarity against teachers as the authority figures even in the context of good relationship with teachers was quite strong during my school years. When I was in $7^{\text {th }}$ grade I had a very good math teacher. She organized an afterschool math circle for students (Matusov, 2017; Shifman, 2005), like me, who were interested in math. She nurtured our math interests and encouraged us to participate in local math Olympics, which eventually led me to apply to a math specialized high school. Once she caught my classmate who was copying my homework just before our math class. After the class, she asked me to stay to talk with her. She told that it was good that I was trying to help my classmate in math because, according to her, it was a duty of all of us, more knowledgeable people, to help less knowledgeable. However, what I did was not help but counter-help. It was counter-help because copied homework would have misled her, my classmate's teacher, thinking that the classmate was capable and knowledgeable of the material while he was not. She told me that to be loyal to my classmate was to be genuinely helpful to him, which in this particular case was to teach him math. She asked me, "Did you offer tutoring him?" I did not. She said that I should genuinely help him and her, as his teacher. I promised to do that. I came to my classmate to offer my math tutoring help. He looked at me with surprise and distrust and replied, "Fuck off!" I was thinking of whether I should continue letting him copy my math homework or not and after some hesitation, I decided I would. My then decision was based on four considerations. First, student solidarity was more important than student-teacher relations were. Second, genuine help should be defined by the person who may receive the help (i.e., my classmates) and not providers of help (me) or outsiders (my math teacher). Third, I was concerned that my teacher might abuse our good relations and her welcomed help to me to do her "teacher job." Fourth, I wanted to preserve good relations with my classmates by being helpful to them on their own terms.

\footnotetext{
${ }^{29}$ This Russian word literally means "little knocker". "To knock" is a Russian slang word meaning, "to report on others to the authorities."
} 
Like fights against teachers, academic cheating was another popular theme story among Soviet school alumni. Academic cheating was viewed by the students as honorable. It was collective, and widespread in Soviet schools and often involved a cat-and-mouse game between teachers and students. Soviet students expected teachers to try to catch cheating and punish cheaters if the teachers cared about their job. Soviet teachers knew that cheating was omnipresent. Some Soviet teachers had an illusion that they made cheating impossible but, in my view, it was just that - an illusion. As a physics teacher myself later on, I left the class for my lab during tests I was giving to my students. I could observe the class through the reflection of protective glass on the class clock hanging on the classroom wall. As far as I knew, none of my students realized that. I punished only "obvious and arrogant" cheaters, who cheated openly without trying to hide or copied the text word-by-word from the textbook. I considered cheating a somewhat useful learning activity when students might read the academic text for the first (and often the last) time. However, if I stopped punishing obvious cases, my students might start thinking that I did not care about teaching my dear subject - physics. Once, I had a 10th-grade student who "obviously" cheated by copying text from physics textbook word-by-word, but observing his behavior through the classroom clock, I could not figure out how he did it. I tracked his eyes' look while he was copying from his textbook but there was no textbook there. Finally, I surrendered - I called him to my physics lab and told him, "Look, I know that you copy the textbook but I don't know how you do that. I'll give you B for the test if you tell me your trick." He agreed and showed a clever periscope that he built out of two hidden mirrors. Since it was an optics test, I gave him A for his ingenuity and his practical application of optics. Both he and I proudly but secretly shared this incident among our peers: he with his trusted classmates and I with my trusted colleagues. While in the US schools, academic cheating is often viewed as dishonor, in Soviet schools it, especially creative and ingenious "impossible" cheating, was viewed by students (and even by many teachers informally) as a badge of honor.

Segregated by the student oppositional solidarity to (adult) authority, students' relationships varied from neutral civility, to deep friendships, to open hostilities, to sexual harassment ${ }^{30}$, to bullying, to the agentic state of peer pressure, and so on. As far as I remember, cliques, as self-sustained isolated subgroups based on exclusivity that are widespread in the US, were unknown in Soviet schools. It is probably because of cohort, school-level integrated, smaller Soviet schools. Soviet students spent with each other their formative years attending ALL classes together, having the same teachers, and participating in the same school events. Even enemies knew and connected to each through a network of the other classmates: they knew more or less what was going on in each other lives. The total exclusivity was difficult, unless for some reason a student was ostracized by the near entire class and became a scapegoat (which happened with some marginalized students). In case of student-student conflicts and abuse, many Soviet parents advised their children to learn how to stand their ground and fight bасk ("дать сдачи" ${ }^{\prime 1}$ ) - engaging the school authority in a conflict was a social taboo for many Soviet parents as well (unless it was a very extreme case).

Being physically not very strong, I learned to stand my ground by never giving in to the demands of bullies even when threatened to be beaten by them. In middle and high school, bullying of male students often involved money racketeering. My rule was never to give money to a racketeering bully because if you did it once there would be no end to the racket (Graeber, 2014). When I joined a new high school, I was kicked in my guts by a bully (who was not form my class and was older than me) for refusing to give him 10 kopecks (probably about $\$ 1$ of buying power back then). After that he left me alone. At some point, my and his social networks crossed. Once he needed a few kopeks and I freely offered my money to him, as

\footnotetext{
${ }^{30}$ As far as I can remember, the issues of diverse sexual orientation only registered my consciousness in my late teens mostly as slurs. Homosexuality was considered a crime in the USSR and was punished by hard prison labor.

${ }^{31}$ Literally, "to give change back" in Russian.
} 
my "friend". Next day his racket re-emerged, I refused, and he had ${ }^{32}$ to beat me again. Since then I never offered money to him and never considered him as a part of my social network. However, this was never accurate as our overlapping social networks still interacted - I knew that some of our peers in our shared social networks communicated to the bully to leave me alone, which he did.

Soviet student peer culture contributed both to promoting and to resisting to the agentic consciousness. It promoted the agentic consciousness by providing the normative others who constantly externally and internally monitor and sanction the "deviants" as it was portrayed in the Russian musical "Stilyagi." Thus, I remember that as college male students we had to go to military camp after our $4^{\text {th }}$ year of college in summer, before the last year. We lived in tents on a military base near a big wild flower field. A friend of mine got grass allergy: he could not sleep, coughed and had high fever. It took me a few days to force the military administration to let him leave the camp earlier. Meanwhile, our platoon was late for a breakfast because of him. An officer punished all our platoon because of that (despite the fact that I explained the reason to the officer) - a collective punishment, fostering agentic consciousness, was common in Soviet institutions. To my big surprised our peers were angry at my sick friend and not at the officer, who punished them. A few days before, our platoon lost "dinner privilege" for singing out aloud an obscene song while marching and it was OK for them to be punished but not to be punished for their sick peer. In Soviet colleges based on a cohort system, students spent all their classes, all their parties, all their tests together. My friend was highly liked and respected by his peers. They had disliked the officer whom they called "an asshole." And nevertheless, they were mad at their sick comrade for losing their breakfast and became the extension of the institution in their agentic state.

However, at the same time, the Soviet peer culture created resistance to the authorities through "good laugh" (Willis, 1981) and cheating. In the next section, I will turn to consider this peer culture in details and I will argue that it promoted another type of non-political consciousness in the USSR.

\section{Free-range Soviet childhood and horizontal socialism: The camaraderie consciousness}

Let me start this section with describing free-range ${ }^{33}$ Soviet childhood and then move to description and analysis of peer culture, its socialist relations, and another type of consciousness that I call "the camaraderie consciousness." In my elementary school age, my favorite imaginary play was exploration of an unfamiliar land of my neighborhood. The challenge was to go to an unfamiliar territory, explore it for "interesting things" and predictably come back, which was rather a challenge for me at times (3-11-year old). I especially liked to do it during frequent winter snowstorms in Moscow winters, carrying a stick and imagining myself an explorer of a new, undiscovered, land, overcoming the burden of the nasty weather. Of course, my parents did not allow that. They set up a range of my allowed-to-go territory around our house. But as far as I remember my outside life was never supervised by adults and I could go and do wherever and whatever I wished. I knew that I needed to be back home on our courtyard at certain time and I tried to be there then. But it did not always work.

Thus, even when I was three I went to a local furniture store to look for a new bed from myself. I overheard my parents discussing a need to buy a new bed for me and I decided to check for it by myself. My parents caught me on my way back to home. I miscalculated the time when they came back from work. My older brother, who was 10 at that time, was supposed to look after me but he was busy playing with his

\footnotetext{
${ }^{32}$ A Soviet school bully involved in maintaining his reputation among other kids and could not leave resistance to their money racket without any punishment. Punishing and terrorizing the resistant weak they saved on violence from challenging their informal semicriminal authority.

33 I barrowed the term "free-range childhood" from Appleton and Skenazy (see Appleton, 2002; Skenazy, 2009).
} 
peers as usual. When my parents found me, they looked scared. We lived in a long 5-story building along with two other similar buildings, creating a letter $C$ and, thus, an internal courtyard where I was allowed to stay. The three buildings belonged my father's factory job. Many people living in these buildings worked together and knew each other. When my parents were looking for me, someone from my dad's work told them that they saw me in the furniture store. My parents rushed there only to find the 3-year old me walking back, having hands in my coat pocket, and looking very important. I knew that I transgressed my parents' rules, I was faulty, and I expected a punishment. On the way back, while being scolded by my parents, I seriously asked my dad, "Are you going to beat me with your belt?" He looked at me with surprised and said, "Yes." I was scared and proud. My dad had never beat me before in any way. But he beat my 10 -year old brother with his pant belt to discipline him. When we came home, I pulled down my pants and underwear and laid down on a sofa preparing for the execution. My dad took his belt and very gently, almost symbolically hit me several times. I pretended to be hurt but "stoically" did not cry. After this mature discipline procedure that I took as my rite of passage, I ran to my older brother bragging to him about my bravery and accusing him of being a sissy because he often cried after being beaten up by my dad for his transgressions. This was usually at times when he, my older brother, really beat and hurt me, and I was only saved by my parents.... After this incident, my dad stopped using any corporeal discipline on my brother (and, of course, on me). My sense is that around the early 1960s, something happened in the Soviet parenting culture in the intelligentsia ${ }^{34}$ class and, especially, in Jewish Moscow intelligentsia, and the parents stopped using corporeal discipline for their misbehaving children ${ }^{35}$. Later, some of my less lucky peers envied me for that. So far, I do not know what happened around that time and why and how widespread was that phenomenon of stopping using corporeal punishment by Soviet (Jewish?) intelligentsia parents, but it was true for some of my peers from intelligentsia families.

Back to my elementary school days of an imaginary explorer. My exploration and colonization of more and more remote areas was gradual and methodical. I was searching for unknown "interesting things" varying from radio parts to live bugs or unusual plants. State garages, enterprises, factories, railroad depots, railroad tracks, construction sites, parks, water pounds and, yes, even garbage cans were sources of my potential treasure. I brought some "treasure" to home (including, for example, a sick pigeon suffering from diarrhea - it died on our balcony) but I meticulously hid some other "treasure" outside knowing well that it would never be allowed in by my parents. Still, I smuggled some other "treasure" in and hide it at home without my parents' permission. With multi-age kid gangs from my building and the surrounding buildings, my exploration of adjunct territories and even remote districts of Moscow was rapid, purposeful, and more "secure" - i.e., I did not need to worry about how to come back reliably on time as older peers guided younger peers. We traveled on buses, often without pay (“зайцем" - i.e., like a hiding bunny) to watch amazingly colorful and mind-blowing Japanese animations to cinema theaters located in other districts of Moscow. We went to a big water pond for fishing or mock fights on self-made rafts (a rather dangerous game as I look at it now ${ }^{36}$ ).

\footnotetext{
${ }^{34} \mathrm{https}: / /$ en.wikipedia.org/wiki/Intelligentsia

35 American serial "Mad Men" nicely portrayed a similar parental dilemma of stopping corporeal punishment of their children in American middle-class families around the same time.

${ }^{36}$ Other dangerous playful activities involved putting nails - as big as possible -- on the railroad trails so a passing train would make "swords" out of them. Getting sulphur from a railroad - dropped from passing trainloads - and burning it. Playing with liquid metal balls of mercury from a broken thermometer. Making gun powder. Making various guns with real striking power. Blowing up carbide. Playing with knives. Smoking paper, tea leaves, and tobacco, and so on http://supercoolpics.com/samye-nebezopasnye-veshhikotorymi-razvlekalis-deti-v-sssr/?fb_ref=3d8f978964de48449a7778d88583674a-Facebook
} 


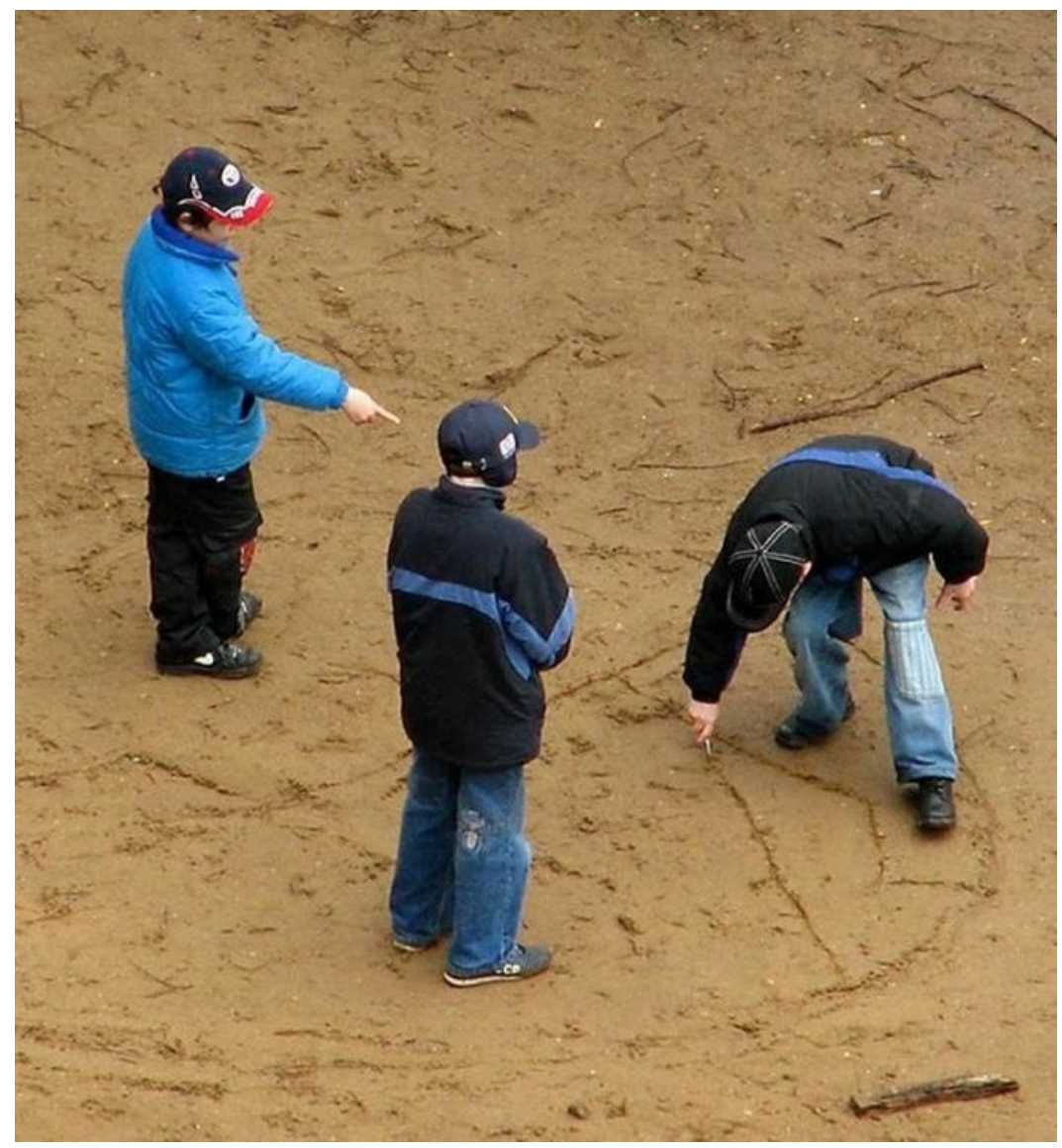

Picture 8. We often played a game called "knives." We drew a circle divided equally among the number of participants. Each stood on his land. Then the participant stuck a knife in the standing portion of the enemy and cut off a piece of his land as much as he could get while staying on his own territory. If one's knife was "wounded" (was not stuck or missed the other's territory) - the move was transferred to the next participant. And by the same rules we had all the time to stand on their own land as long as you can. According to other rules, one could be outside, but in the event of a catastrophic reduction in your area, the enemy offered you three seconds to stand on it. If you cannot resist - you are eliminated from the game. The stand can be even one foot on tiptoe - the main hold for three seconds. http://supercoolpics.com/samyenebezopasnye-veshhi-kotorymi-razvlekalis-deti-v-sssr/?fb_ref=3d8f978964de48449a7778d88583674a-Facebook

We went to numerous construction sites for play and search for valuable materials like lead, which could be easily melted and given a desired artistic or pragmatic form (e.g., a skull, a puck, a ball), or colorful plastic twisted wires used for electrical isolation (it could be pricked in a cloth and then melted with a match flame to create very beautiful forms), and so on. Once a construction worker caught me (9-year old), grabbed my arm and dragged me out the site to bring me to a local police station. On the way to the police, I tried to free myself and escape but it was in vain. My peers followed us in distance, verbally assaulting the construction worker and demanding my freedom. Suddenly, I changed my strategy. I stopped trying to free myself, looked straight at the worker eyes and said, "Dear uncle, forgive the asshole" ("Дяденька, прости засранца ${ }^{37 ")}$. The worker stopped with surprise, looked at me, and started laughing. He asked for my word not to get to a construction site again, explained to me how dangerous it was for all and especially for little kids like me, and let me go. My peers were shocked (they could not hear my conversation with the worker) and I gained a lot of respect from them for making the adult do what I wanted him to do. With some initial hesitation, I returned back to constructions sides in a few weeks through peer pressure.

\footnotetext{
${ }^{37}$ Literally, "Forgive this little pooper" in Russian
} 
Older kids (i.e., older preteens and especially teens) in our loose and variable "gangs" had responsibility to physically protect "their own" younger kids from physical and verbal abuse of remote kid "gangs," protect younger and weaker kids inside their own gang, and install justice and order in their "gang." As far as I remember, I was never abused by older kids in my local "gang." I only remember their very gentle and brotherly relationship to me and other kids. I do not remember any ethnic slurs directed at me or my local peers. One of the older boys and his mother gave me the old skates he grew out of, and the whole gang in our yard took responsibility to teach me skating at the self-made courtyard skating ring. They were very patient, supportive and gentle with my mistakes, inabilities, and provided me with their guidance for several days until I mastered the skating skill. Any attempt to calculate favors, which I can hear in middle class cultures in the US (e.g., "now I owe you big"), were actively discouraged in the peer camaraderie culture of my Soviet youth. Peers helped peers because they were friends and not because they expected a return of the favor in the future (Graeber, 2014). The absence of important institutions (e.g., banks), lack of services, poor services, deficits of goods in the Soviet Union promoted these networks of camaraderie. People could "travel" in these networks by getting help (e.g., borrowing money, getting medicine, getting deficit goods) even from strangers, who were friends of friends ${ }^{38}$. Breaking promises were rare because the natural punishment was ostracism from the camaraderie networks, which could be a severe punishment leading to injuries and even death (e.g., being left good adequate medical assistance). In the US, some working class community may have these camaraderie networks (Lareau, 2003) and camaraderie relationships (Graeber, 2014) ) $^{39}$ but their extent and power seem to me much more limited than it was in the Soviet Union.

I had a special position in the local gang. Being a dyslexic, I was a "talented" improvisational storyand joke- teller (including sexual and vulgar ones), creatively modifying movies, jokes, and stories I heard and watched. I could make good laugh out of my lads (cf. Willis, 1981) and was valued and respected for that. I added my own situational "wisdom" and morals of the current events important for my audience and creatively played with intonations. I was also a very good "German Nazi soldier" when we played in the WWII - a very popular boy game of my days - because I could speak "German" fluently - i.e., I could produce unintelligent "German"-sounded gibberish in an aggressive way ${ }^{40}$.

My same-age peers were another story. I was physically weaker than many of my same-age peers were and my "talents" were my protections from my peers' abuse. I had a various alliances and friendships usually, but not always, with ethnically non-Russian peers and I had enemies - kids who tried systematically verbally and physically to abuse my friends and me, often on ethnic grounds but not only (they were mostly, but not always, ethnically Russian). Of course, we paid them back with the same counter-abuse and aggression and we also used ethnic slurs against them. Often, we were stronger verbally but weaker physically (and numerically). When an enemy boy did not have his friends around, to hang out and play with, he begged us to join our group. After some humiliation and his promises not to abuse us anymore, he

\footnotetext{
${ }^{38}$ When I arrived in the US, I asked to borrow a few hundred of dollars from an American university colleague to buy an old used car, which was so necessary there. I was shocked that my colleague advised me to go a bank and that she was upset with me that I "forced her to refuse." I was upset too, because I considered her a friend and her reply was culturally inappropriate for my Soviet camaraderie culture.

${ }^{39}$ In his 2014 book, David Graeber called it a "communist relationship" based on the communist principle, "From each according to his ability, to each according to his need" promoted (but not invented) by Karl Marx

https://simple.wikipedia.org/wiki/From each according to his ability, to each according to his need. I respectfully disagree with David Graeber (and Karl Marx) because the camaraderie relationship is not based on "from each according to his ability" in this relationship and network - nobody demands abilities from others in camaraderie - rather people contribute to their friends, neighbors, family members by whatever they can offer or have taking care of each other's needs.

${ }^{40}$ However, I was not happy about this role because at the end of any WWII game, I was half-playfully half-seriously beaten as a German Nazi soldier. When I protested to play a German Nazi soldier - I wanted to be a Russian Soviet soldier to play, the most desirable-respectful play role, - my peers refused arguing that I had "perfect German" to speak. They also mentioned that I could abuse them, playing Russian Soviet soldiers, always at the beginning of the play (which was a dangerous and stupid move because I would be triple beaten by them as a revenge at the end of the play).
} 
would be allowed to join us only to break his word when his friends appeared. We could not do the same (despite a temptation) because we knew that we would never be let in. Later, in our late 40s, via email, a former Russian enemy of mine apologized for his Anti-Semitic abuse of me that, as he said, he learned from his mother. The irony was that not only he married a Jewish woman but also worked in one of Hassidic Jewish private schools in Moscow, while remaining a big enthusiast of Russian and Slavic traditions, songs, and folklore.

The Soviet mythological ideology penetrated our free-range Soviet childhood and playworld as well: we lived in constant anticipation of coming war. Thus, when I was 10 in 1970, all my peers - older and younger -- and I were sure that in there would a war with China in 1975. We tried to prepare ourselves by learning how to jump over fences and by playing various games of withstanding suffering. For example, we competed on how long each of us could hold a hand in extremely hot or cold water. We wanted to become a pioneer-hero ${ }^{41}$ - young children, members of Communist youth organization, of the past who fought Nazi German soldiers, White Guard troops ${ }^{42}$, foreign spies, and kulaks ${ }^{43}$. I do not remember how we decided that the war with China would start in 1975 - but we all were sure that it was well known fact ${ }^{44}$.

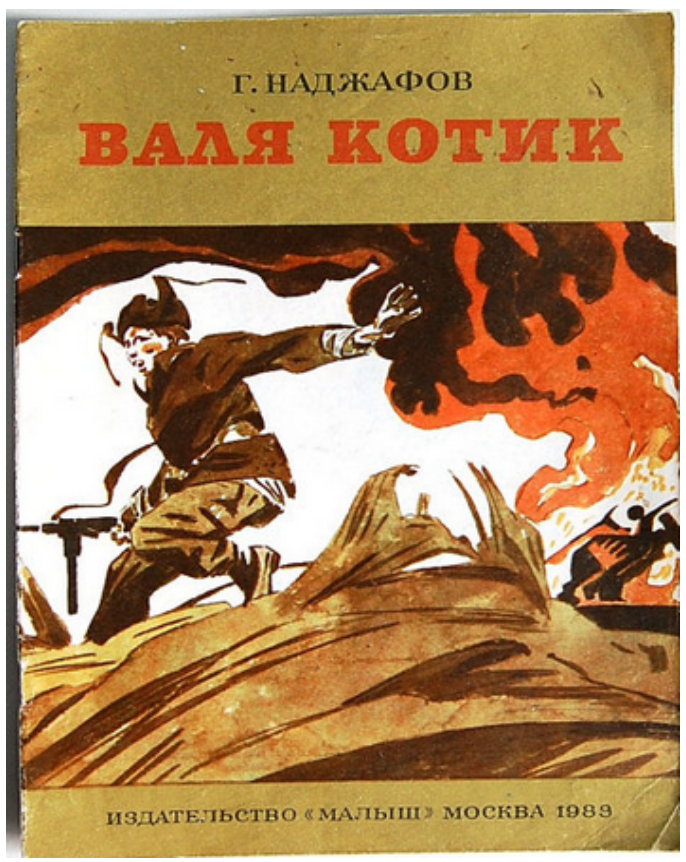

Picture 9. Book cover about a pioneer-hero Valya Kotik written by Nadzhafov for elementary school children

\footnotetext{
${ }^{41}$ In school and at home, we read books about pioneer-heroes.

42 Anti-Communist military force during Russian Civil War, 1918-1921, https://en.wikipedia.org/wiki/White movement.

${ }^{43}$ Well-to-do peasant. "According to the political theory of Marxism-Leninism of the early 20th century, the kulaks were class enemies of the poorer peasants. Vladimir llyich Lenin [the first Communist leader of the USSR] described them as 'bloodsuckers, vampires, plunderers of the people and profiteers, who fatten on famine.' Marxism-Leninism had intended a revolution to liberate poor peasants and farm laborers alongside the proletariat (urban and industrial workers). In addition, the planned economy of Soviet Bolshevism required the collectivisation of farms and land to allow industrialisation or conversion to large-scale agricultural production. In practice, government officials violently seized kulak farms and murdered resisters; others were deported to labor camps" https://en.wikipedia.org/wiki/Kulak.

${ }^{44}$ In March of 1969, there was a Sino-Soviet border conflict that probably shaped our child mentality https://en.wikipedia.org/wiki/SinoSoviet_border_conflict.
} 
At the same time - all Western things - ball pens, toys, foreign coins, chewing gum, pins, dress were objects of admiration and envy - the possessions by a very few lucky ones. I remember a boy from our 5-store house building where I lived brought a piece of American chewing gum (I did not know where he got it). We all begged him to give us a small piece of it. He generously shared it from his mouth and we all in line chewing the recycled gum with pleasure trying to imagine the taste of the original chewing gum. We knew that begging chewing gum and other Western treasure from foreigner visitors was a political criminal act but we also knew that some kids did it. We heard stories of children being recruited by foreigners to become spies after they begged the foreigners for chewing gum and jeans and hung around hotels, wher Soviet citizens were forbidden to visit. We had ambivalent feeling of moral disgust and envy/admiration of those kids.

My boy playworld was centered on the issue of gaining personal power and escaping from power of others. For many years, my friends and I played in an imaginary feudal state where I was the Emperor. We had our own money ("mazi" - abbreviation for the first letters of our last names - the kids who initially formed our imaginary State) that was backed with pieces of amber that I collected on the Baltic Sea, where I visited with my parents for a summer vacation. We had the map of our imaginary State based on the geographic counter maps that we got in school and a map of Moscow that I "borrowed" from my parents without permission. Later our State was involved in scientific enterprises such as building the Time Machine to move to pre-revolutionary Russian Tsarist Empire in order to buy a ship ticket for the Chatham Islands near Australia with its very mild weather around the year and no dangerous predators. For this project, we self-studied physics (the theory of Relativity), geography, and history and collected old tsarist money. I wonder if many child fantasies of free travel were our tacit responses to the fact that we lived behind the iron curtain and could not freely travel beyond the Soviet borders.

We also "built" a "powerful" laser out of my film projector to control the world. ${ }^{45}$ This resulted in a huge explosion in my room when I tested the "laser" trying to cut my school building in half at night when nobody was in school (we lived on the fifth floor and windows of my room were opposed my "beloved" school). This fantasy was my rather clear response to an oppressive nature of Soviet schooling.

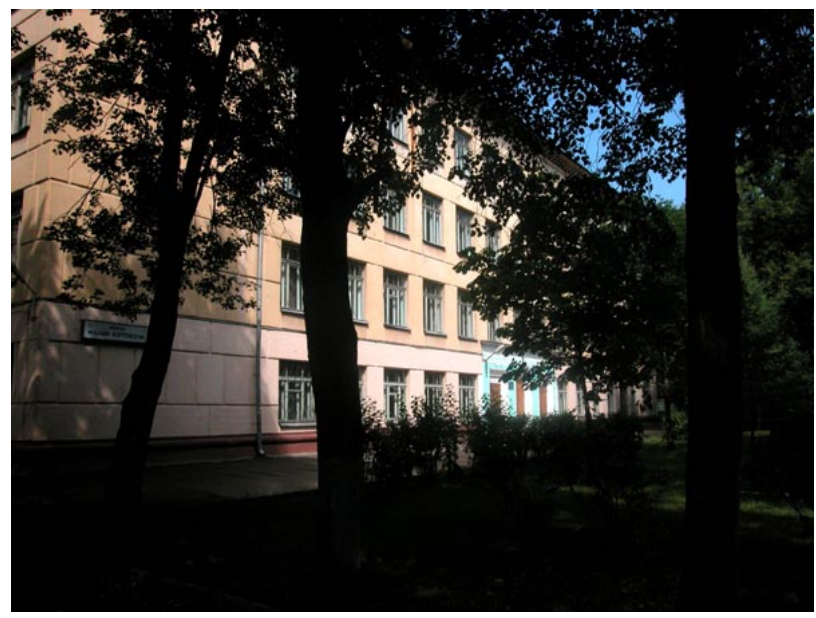

Picture 10. My "beloved" school 145, on which I tried my "laser" to cut in half (photo is mine). I attended it from 1968 until 1974

45 This fantasy was based on a popular Soviet science-fiction novel and then film "The Hyperboloid of Engineer Garin" by Alexey Tolstoy, 1927. 
Fortunately, miraculously I was not hurt - the lenses of the film projector were melted, the metal was twisted, the plasticine that used to cover all gaps in the "laser" was boiled and spread all over the ceiling and walls of my room. I did not tell to my parents what happened despite of multiple interrogations - I heroically kept silence "like a Soviet captured partisan at a Nazi-German interrogation," as we often used to say. Another "remont" (remodeling) of my room was due... My friends and I also built a machine to use the electrical field to subdue our bullies by sucking physical energy from them. My then tests on insects gathered inconclusive evidence about how effective was the machine.

In pre-tween age, boys could play with girls and flexible alliances could be built. However, it quickly became a social peer taboo for tweens - preteens and early teens. Our gangs run by older teen boys protected and respected girls in general: their girl-friends and their female friends of their girl-friends were even allowed in the gang. Vulgar sexually loaded language, jokes and stories were not allowed in the presence of these older teen girls and younger boys were severely punished for violation of this unwritten rule. However, without the presence of these older teen girls, the culture of machismo, sexual slurs, bravado, sexual objectification of women and girls, glorification of sexual violence, pornography ${ }^{46}$, male sexual fantasies, and working-class language loaded with sexual innuendos were flourishing. At my home, my intelligentsia parents did not use non-normative language (beyond jokes that demanded that) but in my working-class peers' homes, I visited, that language was often an everyday norm. In my preteen and early teen ages, the relationship to girls was openly hostile among my same age peers. Mutual sexual verbal abuse between the genders was very common as well as physical abuse (as a part of her gender aggression a girl broke my arm although non-intentionally by suddenly pushing me from behind so I felt down with a bad luck). Sex abuse and sexual harassment of girls by boys by violent touching and groping the girls' private parts was common. However, it usually targeted some girls that had a "slutty" reputation justifying that "they wanted that or asked for that", which was a pure lie as far as I could remember (Livschiz, 2008). Usually, the "slutty" girls were marginalized from girls' networks and did not had powerful older boy protections (e.g., older boy gang leaders, powerful older brothers and so on). I did not hear about rape but I would not be surprised if it were some tragic unreported cases of it (Livschiz, 2008). Like probably many other boys, I personally was torn apart between my sympathy for the abused girls, my desire to fit to the boy macho culture, and excitement of abuse and sexual excitements and experimentation. Although, on average, being a marginalized boy myself because of my non-Russian, Jewish, ethnicity, my physical weakness, and my intelligentsia class background, it was easier for me to side with the oppressed than with the oppressors - I, as a boy, tried more to protect girls and stopped the abuse than to join it. My parents noticed and commented to me (often with their disapproval) that I often hanged out and befriended with "unfit" kids: marginalized, loners, mentally challenged, D- and F-students, and so on.

At the same time, the gender segregated world of girls was mysterious for us, boys. Thus, in fourth grade, I felt in love with a girl, who to my surprise replied with her friendship to me. But soon, I became perplexed as I liked to be near her but I did not know what we could do together. Her girly fantasies and plays were boring for me and my boyish fantasies and plays did not appeal to her. Our gendered and segregated worlds were very apart. Our friendship and my romantic relationship to her (I did not know if she had any romantic relationship to me) were sexualized and vulgarized by my peers (my friends tried to respect me and did not participate) that embarrassed me. My parents commented that "look, he already had a girlfriend", which both made my proud of my coming maturity and more unease at the same time. So,

\footnotetext{
${ }^{46}$ For the first time, I faced pornography when I was 9-year old when older peers from my house building shared adult self-made pornographic black-and-white photos of adult people, males and females, in their late twenties and early thirties engaging in sex and mutual masturbation. I had no clue how my older peers got hands on these porno photos. Of course, I was surrounded by pornograffiti from my early years (on walls of buildings and in public toilets, including in school), which contributed to my sex education, although, probably, highly inaccurate.
} 
in a few months I broke our friendship and stopped coming to her, calling her, and replying to her phone calls and invitations to play and hang out.

The children multi-age world was completely impenetrable by the adults. Adults tried to read clues and evidence of kids' lives neglectfully left by the kids. However, through same and older peers/siblings' guidance and apprenticeship the kids often quickly improved their hiding, masking, and lying skills. Thus, my mom told me at my early elementary school age that she could see long distance through walls when I "unlawfully" ate chocolate candies or poured unwanted soup into a toilet bowl. I initially believed her. But my older brother taught me to cover poured soup in the toilet with detergent to avoid greasy spots on the water and not to throw candy wrappers into the kitchen garbage can so our mother would not notice my food abuse. We learned not to engage parents, neighbors, parents of our friends, teachers, and adult authorities in our interpersonal conflicts and pains and not to report on each other to them (despite obvious benefits of that at times). We learned to suffer silently and secretly from bullying, peer abuse, violence, peer ostracism, and even sexual abuse. The only legitimate adult protection was running into a visible proximity of familiar adults for silent observable protection - our perpetrators would not dare to abuse us in the presence of these adults. Our community behind ${ }^{47}$ was our siblings, friends, gangs, peers, classmates, and neighborhood kids.

I think this is how children's powerful socialization into horizontal networks of informal support in opposition to the authorial hierarchies emerged in the Soviet Union. Friendships and gangs were extremely egalitarian societies. These societies were open and not closed as youth cliques in the US because all children, even our personal enemies, scapegoats, and loners were engaged and connected into meta horizontal networks of support, loyalties, and alliances of friendships, gangs, former and current classmates, neighborhoods, siblings, families, children of family friends, and so on. Sharing was unconditional and non-reciprocal, in a sense that it was not a calculated exchange, "I do a favor to you and you will obligated to do me a favor in the future." Any attempt to remind someone about past favors was a subject of disapproval and, if continued and insisted, a subject of peer sanction or even expulsion and ostracism. Buddy generosity, relational unconditionality, incalculability and self-sacrificing for your buddy/friend as the most important social values ruled. It was "real socialism" that we knew...

\section{Conclusion}

Looking back on my own and my peers' Soviet upbringing and teaching, I have abstracted eight diverse types of consciousness - somewhat internally consistent types of subjectivity. This does not mean that all Soviet people experienced all of these types of consciousness or that there were not circulated some other types of consciousness, unfamiliar to me or not discussed here ${ }^{48}$. Furthermore, the described eight types of consciousness or even the phenomenon of the multiplicity of consciousnesses is not, in my view, necessarily the birthmark of the Soviet Socialist Totalitarianism. I suspect - this is my plausible hypothesis - that a multiplicity of consciousness is probably common to all types of societies and political regimes. However, the described particular types of consciousness and their relationships with each other may characterize the Soviet Socialist (Post)Totalitarian society. The ubiquity of the five types of the political ${ }^{49}$ consciousness - critical, performative, fanatical, underground, and dissident - was expression

\footnotetext{
${ }^{47}$ A community taking seriously and supportive a person's voice (Bakhtin, 1999; Matusov, 2009).

${ }^{48}$ For example, a market consciousness of measured exchanges - measured exchanges of favors and goods - became increasing stronger with the Soviet Union coming to its collapse. Another consciousness that the Party-State constantly fought was a consciousness of authorial agency based on creativity and personal initiative and responsibility.

${ }^{49}$ Political in a narrow sense of actively addressing and replying to the official Soviet political ideology. Of course, the Totalitarianism makes all consciousnesses and spheres of human activity politically-ideological regardless the inherent orientations of these spheres itself. In the Stalinist USSR, such innocent, inherently apolitical, activities as a collection of post stamps or coins could suddenly become as a political crime (Solzhenitsyn, 1974a).
} 
and reflection of totalitarianism, where the only legitimate power was the power of the Party-State, where ideology is total, and where private sphere is subordinated to the public sphere. The following Soviet joke nicely captured this political-ideological totality, "Animals are in a prison cell discussing the reasons for their incarceration. Fox stole a chicken. Wolf killed a dog. Bear reaped a calf. But Rooster sits away from the rest and keeps silence. Fox asks, 'Rooster, why have you been incarcerated? What for?' Rooster replies, 'I'm not like you! You are common criminals but I'm a political prisoner. I peck a pioneer ${ }^{50}$ in his butt." In a country, where almost every deed was viewed as political, non-political types of consciousness - marginal, agentic, and camaraderie - were often also sucked into political orbits. Thus, people who may too passionately complain to the authorities about a leak in their home roof might end up getting the same psychiatric treatment as political dissidents $\mathrm{did}^{51}$.

I also want to touch briefly on the relationship between Socialism and Totalitarianism. Can Socialism at large exist without slipping down into Totalitarianism (Hayek, 1994)? In my investigation of multiple consciousness in my memoir, I found an oasis of "real" socialism outside of Soviet Totalitarianism in the Soviet peer culture. It is probably not by chance that the Soviet official greeting "tovarisch," which lost its all original meaning in my time ${ }^{52}$, had come from a peer culture of camaraderie. The Soviet Party-State officialdom had rather ambivalent attitude toward this culture of real Socialism. It accepted and encouraged the camaraderie peer socialist relations as an ideological ideal of its doublespeak, while fighting these relations as a "corruptive" and "anti-Soviet" source of power outside of itself. Similarly, the camaraderie consciousness seemed both to benefit and to suffer from the Soviet Socialist Totalitarianism. Thus, my question about a possibility of a full-scale Socialism without Totalitarianism remains open, based on my observation of the complicated relationship between them in the Soviet Union. Besides the issue of possibility, the issue of desirability of the camaraderie consciousness at large is also open, if not problematic, because of its inherent resistance to diversity and its hidden pressure for conformity - i.e., peer pressure, camaraderie agentic state ${ }^{53}$.

Finally, I want to add a critical note about my investigation of children's socialization into Soviet multiple consciousness. It should be cautioned that I presented only one historical slice of it. There is a plausible hypothesis that the Soviet Union's collapse of its totalitarian political regime was in high degree due to the fact that it could not ontogenetically reproduce itself through its incorporation of new generation: the totalitarian consciousness of performative and especially fanatical types of consciousness gave place to other types of consciousness - critical, underground, dissident - which overtook the new generations of Soviet people. This interesting development hypothesis needs its further investigation.

\section{References}

Appleton, M. (2002). A free range childhood: Self-regulation at Summerhill School. Essex: Gale Centre Publications,. Arendt, H. (1966). The origins of totalitarianism (New ed.). New York,: Harcourt.

Bakhtin, M. M. (1984). Rabelais and his world (H. Iswolsky, Trans. 1st Midland book ed.). Bloomington: Indiana University Press.

Bakhtin, M. M. (1999). Problems of Dostoevsky's poetics. Minneapolis: University of Minnesota Press.

Bakhtin, M. M., \& Emerson, C. (1999). Problems of Dostoevsky's poetics (Vol. 8). Minneapolis: University of Minnesota Press.

\footnotetext{
${ }^{50} \mathrm{~A}$ member of Communist Youth Soviet organization usually between ages of 9 and 14 .

${ }^{51}$ My aunt, a famous pediatric doctor, was a member of the Moscow Council (soviet) in the 1980s. She told me about this practice.

52 The Russian word "tovarisch" used to mean "companion", "friend" but in my time its meaning firmly belonged to the Soviet officialdom as a reference to a member of the Socialist society. Interestingly, the root of this Slavic word "tovar" means "commodity" and originally "tovarisch" meant a business partner.

53 Thus, I ague, there were vertical agentic consciousness of unconditional surrender to the authority and horizontal agentic consciousness of unconditional surrender to peer and camaraderie. In my observations in the USSR, these two types of agentic consciousness could contradict and complement each other at times.
} 
Bernholz, P. (1991). The constitution of totalitarianism. Journal of Institutional and Theoretical Economics, 147(3), 425440. Retrieved from http://www.jstor.org/stable/40751427.

Buhovtsi, B., Klimontovich, Y. L., \& Myakishev, G. Y. (1982). Physics: Textbook for 9th grade school of the USSR. Msocow, USSR: Enlightment.

Bukovsky, V. K. (1979). To build a castle: My life as a dissenter. New York: Viking Press.

Du Bois, W. E. B. (1961). The souls of black folks. New York: Dodd, Mead \& Company.

Frenkel, E. (2013). The fifth problem. In E. Frenkel (Ed.), Love and math: The heart of hidden reality (pp. 28-38). New York: Basic Books, a member of the Perseus Books Group.

Geertz, C. (1973). The interpretation of cultures: Selected essays. New York: Basic Books.

Graeber, D. (2014). Debt: The first 5,000 years (Updated and expanded edition. ed.). Brooklyn: Melville House.

Havel, V., \& Keane, J. (1985). The Power of the powerless: Citizens against the state in central-eastern Europe. Armonk, N.Y.: M.E. Sharpe.

Havel, V., \& Vladislav, J. (1989). Living in truth: Twenty-two essays published on the occasion of the award of the Erasmus Prize to Vaclav Havel (Paperback ed.). London: Faber and Faber.

Hayek, F. A. v. (1994). The road to serfdom. Chicago: University of Chicago Press.

Huizinga, J. (2009). Homo ludens: A study of the play-element in culture. Oxon U.K.: Routledge.

Ivanova, E. (2000, July). Psychological functions of culture in totalitarian and post-totalitarian societies. Paper presented at the III Conference for Sociocultural Research, Sao Paulo, Brazil. https://www.fe.unicamp.br/br2000/trabs/2220.doc.

King, D. (1997). The commissar vanishes: The falsification of photographs and art in Stalin's Russia (1st ed.). New York: Metropolitan Books.

Kushnir, A., Gurev, S., \& Volkov, A. (1994). The gold underground: The full illustrated encyclopedia of rock-samizdat (1967-1994), history, antology, bibliography. Nizhny Novgorod, Russia: Dekom.

Lareau, A. (2003). Unequal childhoods: Class, race, and family life. Berkeley: University of California Press.

Lemke, J. L. (1990). Talking science: Language, learning, and values. Norwood, NJ: Ablex Pub. Corp.

Lewin, K. (1948). Resolving social conflicts: Selected papers on group dynamics 1935-1946. New York: Harper.

Livschiz, A. (2008). Battling "unhealthy relations": Soviet youth sexuality as a political problem. Journal of Historical Sociology, 21(4), 397-416.

Matusov, E. (2009). Journey into dialogic pedagogy. Hauppauge, NY: Nova Science Publishers.

Matusov, E. (2017). Nikolai N. Konstantinov's authorial math pedagogy for people with wings: Special issue. Journal of Russian \& East European Psychology, 54(1), 1-117, doi: https://doi.org/10.1080/10610405.2017.1352391.

Milgram, S. (1974). Obedience to authority: An experimental view (1st ed.). New York,: Harper \& Row.

Orwell, G. (1992). 1984. New York: Knopf.

Ostrovsky, A. (2015). The invention of Russia: From Gorbachev's freedom to Putin's war. New York: Viking.

Roviello, A.-M., \& Temerson, C. (2007). The hidden violence of totalitarianism: The loss of the groundwork of the world. Social Research, 74(3), 923-930. Retrieved from http://www.jstor.org/stable/40972131.

Shifman, M. A. (2005). You failed your math test, comrade Einstein: Adventures and misadventures of young mathematicians or test your skills in almost recreational mathematics. Hackensack, N.J.: World Scientific. Retrieved from http://www.ftpi.umn.edu/shifman/ComradeEinstein.pdf.

Shteyngart, G. (2014). Little failure: A memoir (First edition. ed.). New York: Random House.

Sidorkin, A. M. (1995). The Communard movement in Russia: The view of a participant. East-West Education, 16(2), 148-159.

Silberman, C. E. (1971). Crisis in the classroom: The remaking of American education (Vintage Books ed.). New York: Vintage Books.

Skenazy, L. (2009). Free-range kids: Giving our children the freedom we had without going nuts with worry (1st ed.). San Francisco: Jossey-Bass.

Snyder, T. (2010). Bloodlands: Europe between Hitler and Stalin. New York: Basic Books.

Solzhenitsyn, A. I. (1974a). The Gulag Archipelago, 1918-1956: An experiment in literary investigation (T. P. Whitney, Trans. 1st ed.). New York: Harper \& Row.

Solzhenitsyn, A. I. (1974b). Live not by lies. Retrieved from http://www.orthodoxytoday.org/articles/SolhenitsynLies.php?/articles/SolhenitsynLies.htm.

Tamruchi, N. O. (1995). Moscow conceptualism, 1970-1990. Roseville East, NSW, Australia: Craftsman House. 
Vershik, A. (2005). Science and totalitarianism. In M. A. Shifman (Ed.), You failed your math test, comrade Einstein: Adventures and misadventures of young mathematicians or test your skills in almost recreational mathematics (pp. 162-170). Hackensack, N.J.: World Scientific. Retrieved from http://www.ftpi.umn.edu/shifman/ComradeEinstein.pdf.

Voronkov, V., \& Chickadze, E. (1997). Leningrad Jews: Ethnicity and context. In V. Voronkov \& E. Zdravomyslova (Eds.), Biographical perspectives on post-Socialist societies: Proceedings of the Seminar Held in St. Petersburg (14-17 November 1996) (pp. 187-191). St. Petersburg: CISR.

Wertsch, J. V. (2002). Voices of collective remembering. Cambridge, UK: Cambridge University Press.

Willis, P. E. (1981). Learning to labor: How working class kids get working class jobs (Morningside ed.). New York: Columbia University Press.

Yurchak, A. (2006). Everything was forever, until it was no more: The last Soviet generation. Princeton, NJ: Princeton University Press.

Zhvanetsky, M. (2001). Collected work (Vol. 2). Moscow, Russia: Vremya.

\section{(cc) $\mathrm{BY}$}

New articles in this journal are licensed under a Creative Commons Attribution 4.0 United States License.

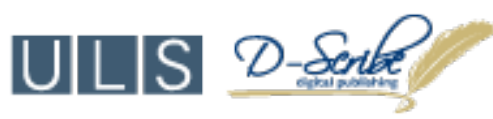

This journal is published by the University Library System, University of Pittsburgh as part of its D-Scribe Digital Publishing Program and is cosponsored by the University of Pittsburgh Press. 